\title{
Intermediate to felsic middle crust in the accreted Talkeetna arc, the Alaska Peninsula and Kodiak Island, Alaska: An analogue for low-velocity middle crust in modern arcs
}

\author{
Matthew Rioux, ${ }^{1,2}$ James Mattinson, ${ }^{1}$ Bradley Hacker, ${ }^{1}$ Peter Kelemen, ${ }^{3}$ Jurek Blusztajn, ${ }^{4}$ \\ Karen Hanghøj, ${ }^{3,4}$ and George Gehrels ${ }^{5}$
}

Received 26 May 2009; revised 7 December 2009; accepted 16 December 2009; published 8 May 2010.

[1] Seismic profiles of several modern arcs have identified thick, low-velocity midcrustal layers $\left(\mathrm{V}_{\mathrm{p}}=6.0\right.$ $6.5 \mathrm{~km} / \mathrm{s}$ ) that are interpreted to represent intermediate to felsic plutonic crust. The presence of this silicic crust is surprising given the mafic composition of most primitive mantle melts and could have important implications for the chemical evolution and bulk composition of arcs. However, direct studies of the middle crust are limited by the restricted plutonic exposures in modern arcs. The accreted Talkeetna arc, south central Alaska, exposes a faulted crustal section from residual subarc mantle to subaerial volcanic rocks of a Jurassic intraoceanic arc and is an ideal place to study the intrusive middle crust. Previous research on the arc, which has provided insight into a range of arc processes, has principally focused on western exposures of the arc in the Chugach Mountains. We present new U-Pb zircon dates, radiogenic isotope data, and whole-rock geochemical analyses that provide the first high-precision data on large intermediate to felsic plutonic exposures on Kodiak Island and the Alaska Peninsula. A single chemical abrasion-thermal ionization mass spectrometry analysis from the Afognak pluton yielded an age of $212.87 \pm 0.19 \mathrm{Ma}$, indicating that the plutonic exposures on Kodiak Island represent the earliest preserved record of Talkeetna arc magmatism. Nine new dates from the extensive Jurassic batholith on the Alaska Peninsula range from 183.5 to $164.1 \mathrm{Ma}$ and require a northward shift in the Talkeetna arc magmatic axis following initial emplacement of the Kodiak plutons, paralleling the development of arc magma-

\footnotetext{
${ }^{1}$ Department of Earth Science, University of California, Santa Barbara, California, USA.

${ }^{2}$ Now at Department of Earth, Atmospheric and Planetary Sciences, Massachusetts Institute of Technology, Cambridge, Massachusetts, USA.

${ }^{3}$ Lamont-Doherty Earth Observatory, Earth Institute at Columbia University, Palisades, New York, USA.

${ }^{4}$ Department of Geology and Geophysics, Woods Hole Oceanographic Institute, Woods Hole, Massachusetts, USA.

${ }^{5}$ Department of Geosciences, University of Arizona, Tucson, Arizona, USA.

Copyright 2010 by the American Geophysical Union. 0278-7407/10/2009TC002541
}

tism in the Chugach and Talkeetna mountains. Radiogenic isotope data from the Alaska Peninsula and the Kodiak archipelago range from $\varepsilon_{\mathrm{Nd}}(\mathrm{t})=5.2$ to 9.0 and ${ }^{87} \mathrm{Sr}^{86} \mathrm{Sr}_{\text {int }}=0.703515$ to 0.703947 and are similar to age-corrected data from modern intraoceanic arcs, suggesting that the evolved Alaska Peninsula plutons formed by extensive differentiation of arc basalts with little or no involvement of preexisting crustal material. The whole-rock geochemical data and calculated seismic velocities suggest that the Alaska Peninsula represents an analogue for the low-velocity middle crust observed in modern arcs. The continuous temporal record and extensive exposure of intermediate to felsic plutonic rocks in the Talkeetna arc indicate that evolved magmas are generated by repetitive or steady state processes and play a fundamental role in the growth and evolution of intraoceanic arcs. Citation: Rioux, M., J. Mattinson, B. Hacker, P. Kelemen, J. Blusztajn, K. Hanghøj, and G. Gehrels (2010), Intermediate to felsic middle crust in the accreted Talkeetna arc, the Alaska Peninsula and Kodiak Island, Alaska: An analogue for low-velocity middle crust in modern arcs, Tectonics, 29, TC3001, doi:10.1029/2009TC002541.

\section{Introduction}

[2] Recent seismic studies of modern intraoceanic arcs have provided new insight into the structure and composition of the intrusive crust. Data from the Aleutian arc are interpreted to reflect a basaltic crust built around an existing oceanic plate [Holbrook et al., 1999; Lizarralde et al., 2002; Shillington et al., 2004; Van Avendonk et al., 2004]. In contrast, studies of the Izu-Bonin [Suyehiro et al., 1996; Takahashi et al., 1998; Kodaira et al., 2007a, 2007b], Mariana [Takahashi et al., 2007; Calvert et al., 2008], Tonga [Crawford et al., 2003], and South Sandwich [Larter et al., 2001; Leat et al., 2003] arcs have all documented thick $(\sim 2-8 \mathrm{~km})$, low-velocity $\left(\mathrm{V}_{\mathrm{p}}=6.0-6.5 \mathrm{~km} / \mathrm{s}\right)$ midcrustal layers that are interpreted to represent intermediate to felsic plutonic rocks. This interpretation is corroborated by the presence of extensive tonalitic plutons in exposed middle crust from the Izu-Bonin arc, preserved in the Tanzawa plutonic complex, Japan [Kawate and Arima, 1998]. The presence of a silicic middle crust is surprising given the mafic composition of most primitive mantle melts, and could have important implications for the chemical evolution and bulk composition of arcs, and ultimately, the role of 


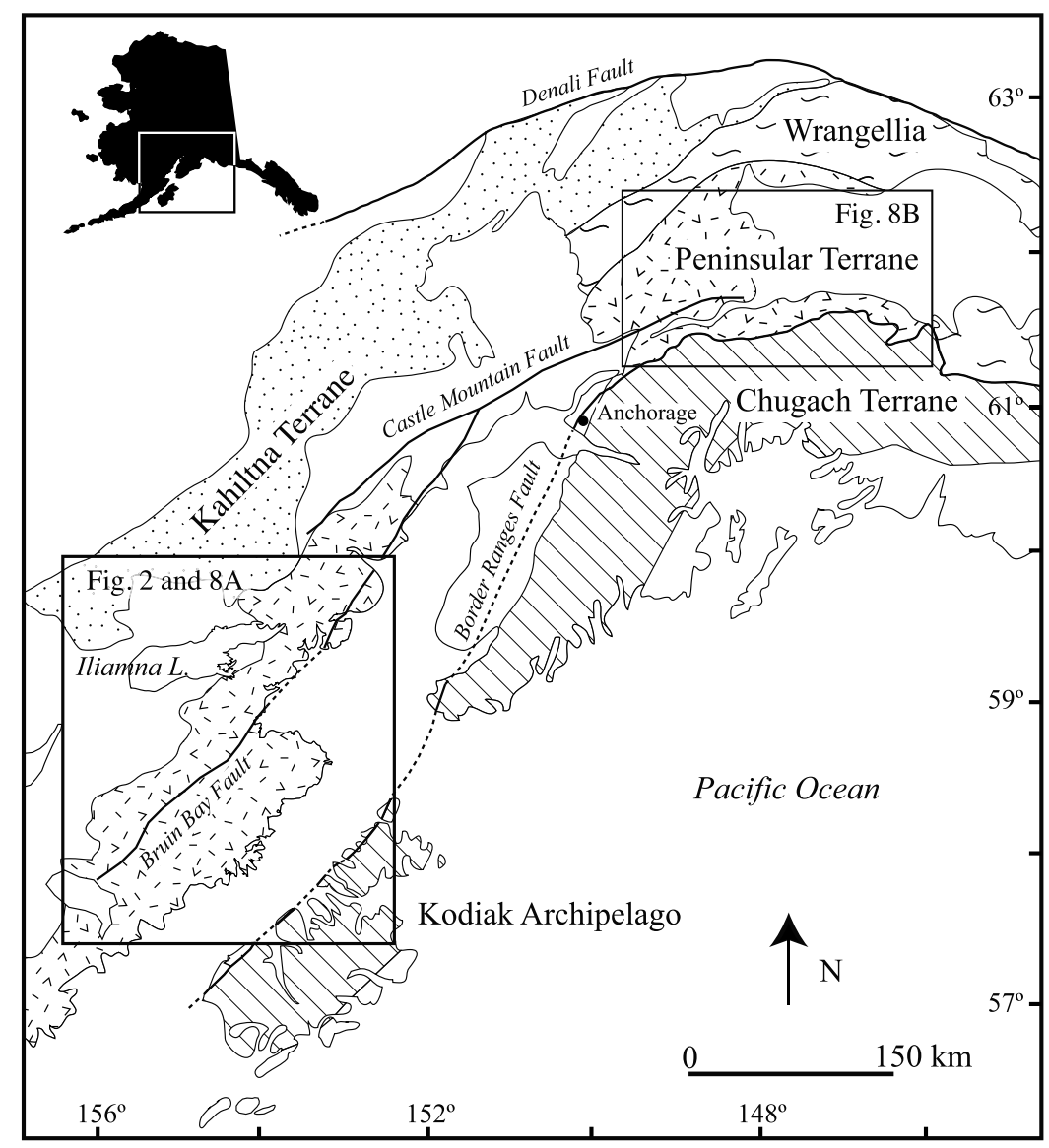

Figure 1. Terrane map of south central Alaska [after Silberling et al., 1994]. The Talkeetna arc defines the extent of the Peninsular terrane. Boxes show locations of Figures 2 and 8 a (Alaska Peninsula and Kodiak archipelago) and Figure 8b (Chugach and Talkeetna Mountains).

intraoceanic arcs in the generation of continental crust. Seismic imaging of arcs provides key constraints on coarse crustal structure, but afford only limited information on the temporal evolution of felsic magmatism and the chemical composition of the intrusive plutons.

[3] The accreted Talkeetna arc in south central Alaska is an exemplary case of an intraoceanic arc crustal section and provides an opportunity to directly study arc middle crust. The Triassic to Jurassic arc is exposed in four volcanic and plutonic sections in the Chugach Mountains, the Talkeetna Mountains, the Kodiak archipelago and the Alaska Peninsula (Figure 1). Previous research has principally focused on the Chugach Mountains, which preserve a faulted crustal section from residual subarc mantle to subaerial volcanic rocks [DeBari and Coleman, 1989; Kelemen et al., 2003a, 2003b; Mehl et al., 2003; Behn and Kelemen, 2006; Greene et al., 2006; Hacker et al., 2008]. The Jurassic batholith on the Alaska Peninsula is distinctly more felsic than the crustal section in the Chugach Mountains and has the potential to provide new insight into the role of silicic magmas in intraoceanic settings. In this contribution, we present new $\mathrm{U}-\mathrm{Pb}$ zircon ages and whole-rock major element, trace element and radiogenic isotope data from western exposures of the arc on the Alaska Peninsula and the Kodiak archipelago (Figures 1 and 2). Our new data demonstrate a temporal link between the four Talkeetna arc exposures and record the tectonic evolution of the arc from $\sim 212-153 \mathrm{Ma}$. The wholerock geochemical data, isotopic analyses, and calculated seismic velocities from intermediate to felsic plutonic rocks on the Alaska Peninsula suggest that this area represents an analogue for the low-velocity middle crust of modern arcs

Figure 2. Geologic map of the Alaska Peninsula and the Kodiak archipelago showing sample locations (Table 1) and the distribution of $\mathrm{U}-\mathrm{Pb}$ zircon ages (in Ma) reported herein. Errors are reported at the 95\% confidence level. The geologic map is modified from Detterman et al. [1976] (Kenai), Connelly and Moore [1979] (Kodiak), Detterman and Reed [1980] (Iliamna), Nelson et al. [1983] (Lake Clark), Detterman et al. [1987] (Karluk), Riehle et al. [1993] (Katmai), and Bradley et al. [1999] (Seldovia). The U-Pb zircon age from the Malina Bay region of the Afognak pluton is from Roeske et al. [1989]. The legend includes rock units shown in this figure and in Figure 8. 

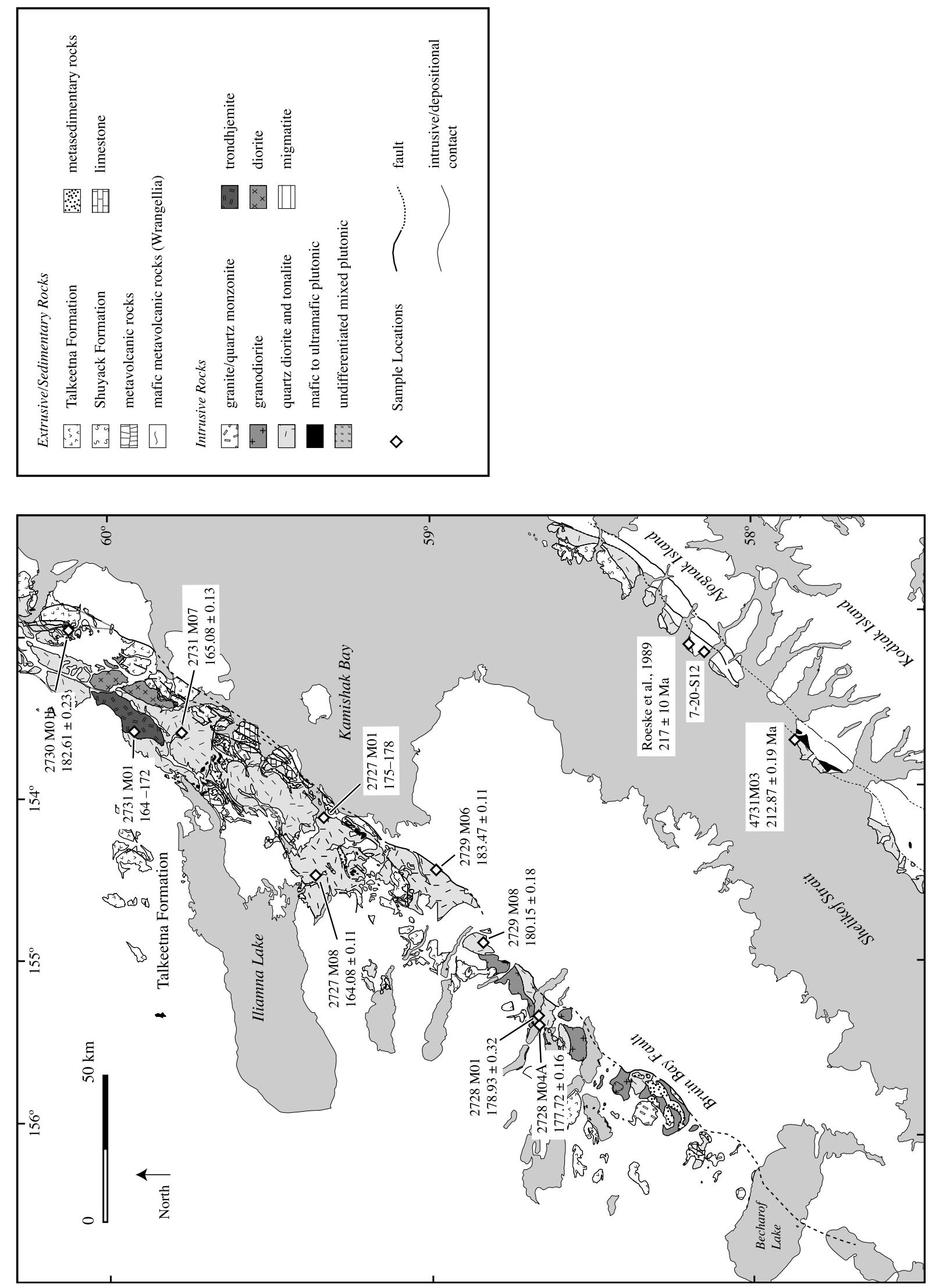

证 
and can be used to understand the role of evolved magmas in intraoceanic settings.

\section{Geologic Setting}

[4] The Talkeetna arc stretches for $\sim 1000 \mathrm{~km}$ across south central Alaska. The volcanic carapace of the arc is preserved as the Jurassic Talkeetna Formation, which is in faulted and intrusive contact with the large arc plutonic complexes. The Talkeetna Formation and overlying sedimentary sequences define the extent of the Peninsular terrane described by Jones and Silberling [1979] (Figure 1). To the northeast, the arc is in faulted and/or intrusive contact with the allochthonous Wrangellia terrane, an extensive Triassic flood basalt erupted through an existing Paleozoic arc sequence [Bond, 1973; Richter and Jones, 1973; Nokleberg et al., 1985, 1994; Barker et al., 1994]. The Wrangellia terrane extends from southern Alaska to Vancouver Island, British Columbia. The southern portion is intruded by the Jurassic Bonanza arc, which some authors have argued represents a southern extension of Talkeetna arc magmatism [Plafker et al., 1989; DeBari et al., 1999], though this relationship is debated. Overlap assemblages suggest that the two terranes formed as a single tectonic block or were juxtaposed prior to accretion onto the continental margin [Plafker et al., 1989; Nokleberg et al., 1994]. The Peninsular and Wrangellia terranes lie outboard of the Kahiltna terrane (Figure 1), a thick section of flysch and turbidite deposits [Nokleberg et al., 1994] interpreted to represent back-arc sedimentary sequences that were deformed during Jurassic to Cretaceous docking of the terranes [Wallace et al., 1989; Ridgway et al., 2002]. To the south, the Talkeetna section is juxtaposed with coeval and younger accretionary complexes of the Chugach terrane across the Border Ranges fault system (Figure 1) [Sisson and Onstott, 1986; Pavlis et al., 1988; Roeske et al., 1989; Clift et al., 2005b].

[5] In this contribution we focus on arc plutonic rocks from the Alaska Peninsula and Kodiak archipelago. The Jurassic batholith on the Alaska Peninsula includes gabbroic to granitic compositions, but is dominated by quartz diorite and tonalite plutons (Figure 2) [Detterman and Reed, 1980; Riehle et al., 1993]. The plutonic rocks intrude and are structurally overlain by a thick section of volcanic breccias, lava flows, and tuffs [Detterman and Reed, 1980] that have been correlated with the Jurassic Talkeetna Formation in the Chugach and Talkeetna Mountains. A range of Jurassic and older metasedimentary and metaigneous screens are preserved within the plutonic section, which together with limited undated (inferred Triassic) metabasalt and Triassic limestone exposures, are interpreted as the only preserved prearc basement [Detterman and Reed, 1980]. To the southeast, the plutonic and volcanic exposures are truncated by the Bruin Bay fault system and juxtaposed with coeval and younger fore-arc sedimentary sequences [Detterman et al., 1976; Detterman and Reed, 1980; Detterman et al., 1996].

[6] The Triassic to Jurassic section on Kodiak, Afognak and Shuyak islands consists of the Afognak pluton, associated mafic and ultramafic rocks, and the Shuyak Formation volcanic rocks. The Afognak pluton includes a series of diorite, quartz diorite, and tonalite intrusions along the northern edge of the archipelago (Figure 2) [Connelly and Moore, 1979; Roeske et al., 1989]. The pluton intrudes the base of the Late Triassic Shuyak Formation, which consists of a lower volcanic unit of vesicular pillow lava and an upper sedimentary unit of volcaniclastic sandstone, conglomerate, argillite, and tuff [Roeske et al., 1989]. The stratigraphic position of the Shuyak volcanic rocks above the Jurassic plutons is similar to the Talkeetna Formation volcanic rocks, however, early to middle Norian fossils from the upper member of the Shuyak Formation are older than radiometric and biostratigraphic ages from the Talkeetna Formation in the rest of the Peninsular terrane [Grantz et al., 1963; Connelly, 1978; Pálfy et al., 1999; Amato et al., 2007]. The plutonic and volcanic units are in faulted contact with blocks of layered gabbro, clinopyroxenite, and dunite within the Border Ranges fault system (BRF). The southernmost strand of the BRF places the Triassic-Jurassic rocks of the Peninsular terrane against the Raspberry Schist, which represents a coeval and potentially related accretionary complex, and younger accretionary mélange units of the Uyak Complex [Connelly and Moore, 1979; Roeske et al., 1989].

\section{Analytical Techniques}

[7] High precision U-Pb zircon ages were determined using the chemical abrasion-thermal ionization mass spectrometry (CA-TIMS) method [Mattinson, 2005]. The CA-TIMS method uses coupled annealing and multistep digestion to minimize or eliminate the affect of $\mathrm{Pb}$ loss in $\mathrm{U}-\mathrm{Pb}$ zircon dating. High-temperature annealing is used to repair radiation damage in the zircon lattice and prevent leaching of radiogenic $\mathrm{Pb}$ during multistep digestions. The zircons are subsequently dissolved in a series of increasing temperature steps. Initial (low-temperature) steps are commonly discordant and have young ${ }^{206} \mathrm{~Pb} /{ }^{238} \mathrm{U}$ ages as a result of geologic $\mathrm{Pb}$ loss. In contrast, the more refractory material dissolves during the higher temperature steps and tends to record the true crystallization age of the zircon. For a homogeneous zircon population, these high-temperature digestion steps are concordant and overlap within error, and we interpret the weighted mean of these steps as the crystallization age of the sample. In this study, large multigrain zircon populations were annealed for $48 \mathrm{~h}$ at $1000^{\circ} \mathrm{C}$ and dissolved in $12 \mathrm{~h}$ steps at temperatures of $80-220^{\circ} \mathrm{C}$ (Data Set $\mathrm{S} 1$ in the auxiliary material). ${ }^{1}$ For a detailed discussion of the chemical abrasion technique, see Mattinson [2005]. Absolute errors for the CA-TIMS analyses follow Rioux et al. [2007]. In addition to the CA-TIMS analyses, we used laser ablation-inductively coupled plasma-mass spectrometry (LA-ICP-MS) U-Pb zircon dating to study the systematics of complex samples. These analyses used analytical and data reduction procedures described by Hacker et al. [2006a] and Rioux et al. [2007].

\footnotetext{
${ }^{1}$ Auxiliary material data sets are available at $\mathrm{ftp}: / / \mathrm{ftp}$.agu.org/apend/tc/ 2009tc002541. Other auxiliary material files are in the HTML.
} 
Table 1. Sample Locations and Rock Types

\begin{tabular}{llcl}
\hline \multicolumn{1}{c}{ Sample } & UTM $(\mathrm{E})^{\mathrm{a}}$ & UTM $(\mathrm{N})^{\mathrm{a}}$ & Rock Type $^{\mathrm{b}}$ \\
\hline \multicolumn{4}{c}{ Alaska $^{\mathrm{a}}$ Peninsula } \\
2727M01 & 0435244 & 6579162 & tonalite \\
2727M08 & 0416606 & 6582598 & tonalite \\
2728M01 & 0364741 & 6507762 & tonalite \\
2728M04A & 0362039 & 6507187 & tonalite \\
2729M06 & 0416543 & 6541058 & tonalite \\
2729M08 & 0390651 & 6525903 & tonalite \\
2730M01B & 0502627 & 6666292 & tonalite \\
2731M01 & 0466290 & 6644241 & trondhjemite \\
2731M07 & 0465440 & 6627797 & quartz diorite \\
& & & \\
& Kodiak Archipelago & tonalite \\
4731M03 & 0456645 & 6416797 & diorite \\
7-20-S12 & 0487250 & 6446640 &
\end{tabular}

${ }^{\mathrm{a}} \mathrm{UTM}$ coordinates are relative to NAD 27. All points are in the 05 UTM zone.

${ }^{\mathrm{b}}$ Igneous rock types follow Streckeisen [1973, 1976] and Le Maitre [2002].

[8] Whole-rock samples for isotopic and trace element analyses were powdered, spiked with ${ }^{149} \mathrm{Sm}^{-150} \mathrm{Nd}$ and ${ }^{87} \mathrm{Rb}^{-84} \mathrm{Sr}$ tracers, and dissolved in the clean laboratory facilities at Boston University following the procedures outlined by Rioux et al. [2007]. Resulting sample solutions were evenly divided for trace element and isotopic analyses. Trace element solutions were converted to $\mathrm{HNO}_{3}$, diluted, and analyzed on the VG PQIIXS quadrupole ICP-MS at Boston University, following the procedures outlined by Kelley et al. [2003]. The ${ }^{85} \mathrm{Rb},{ }^{88} \mathrm{Sr},{ }^{146} \mathrm{Nd}$, and ${ }^{147} \mathrm{Sm}$ intensities were corrected for addition of these elements in the tracer solutions and ${ }^{165} \mathrm{Ho}$ and ${ }^{166} \mathrm{Er}$ concentration were corrected for tracer-related ${ }^{149} \mathrm{Sm}^{16} \mathrm{O}$ and ${ }^{150} \mathrm{Nd}^{16} \mathrm{O}$ interferences by measuring a spiked blank solution. Isotope solutions were transported to Woods Hole Oceanographic Institute (WHOI) for elemental separation and analysis, following the procedures outlined by Rioux et al. [2007]. Major element analyses were carried out on fused samples by inductively coupled plasma-atomic emission spectrometry (ICP-AES) at Boston University, following the procedure outlined by Kelley et al. [2003].

\section{Results}

\subsection{U-Pb Zircon Dating}

[9] We dated 10 samples from the Alaska Peninsula and the Kodiak archipelago (Table 1, Data Set S1, and Figures 2 and 3 ). Eight of the 10 samples generated simple multistep digestion patterns that are typical of homogeneous zircon populations (Figure 3). High-temperature digestion steps from a single sample (4731M03) from the Kodiak archipelago yield a weighted mean ${ }^{206} \mathrm{~Pb} /{ }^{238} \mathrm{U}$ age of $212.87 \pm$ 0.19 Ma (Figure 3j). Seven samples (2729M06, 2730M01B, 2729M08, 2728M01, 2728M04A, 2731M07, and 2727M08) from the Jurassic batholith on the Alaska Peninsula give younger weighted mean ${ }^{206} \mathrm{~Pb} /{ }^{238} \mathrm{U}$ ages of $183.47 \pm$ $0.11 \mathrm{Ma}, 182.61 \pm 0.23 \mathrm{Ma}, 180.15 \pm 0.18 \mathrm{Ma}, 178.93 \pm$ $0.32 \mathrm{Ma}, 177.72 \pm 0.16 \mathrm{Ma}, 165.08 \pm 0.13 \mathrm{Ma}$, and $164.08 \pm 0.11 \mathrm{Ma}$ (Figures $3 \mathrm{a}-3 \mathrm{~g}$ ). All the weighted mean ages yield an MSWD $<1$, with the exception of 2730M01B (1.4), 4731M03 (1.5), and 2728M01 (2.6).

[10] The final two samples from the Alaska Peninsula (2727M01 and 2731M01) have more complex digestion patterns characterized by a spread of data along concordia and a general increase in the ${ }^{206} \mathrm{~Pb} /{ }^{238} \mathrm{U}$ age of the sample with increasing digestion temperatures (Figures $3 \mathrm{~h}$ and $3 \mathrm{i}$ ). Laser ablation-ICP-MS data from one of these samples yielded a single Middle Jurassic population with a limited number of older ${ }^{206} \mathrm{~Pb} /{ }^{238} \mathrm{U}$ ages up to $\sim 200 \mathrm{Ma}(\mathrm{n}=50$; Figure 4 and Data Set S2). The weighted mean ${ }^{206} \mathrm{~Pb} /{ }^{238} \mathrm{U}$ age of the laser ablation analyses agrees well with the span of ages defined by the chemical abrasion analysis. These data are consistent with inheritance of slightly older Jurassic or Triassic zircons into a Middle Jurassic magma. Following this interpretation, the youngest chemical abrasion ages, excluding the low-temperature cleanup steps, provide a maximum crystallization age for the sample and the oldest steps provide a minimum age for the inherited component.

\subsection{Geochemical Data}

[11] Major and trace element data for the dated samples are reported in Table 2 and plotted in Figures 5 and 6. Analyzed samples range from dioritic to tonalitic compositions (Table 1) with 48-76 wt $\% \mathrm{SiO}_{2}$ (Figure 5). Trace element data from the Alaska Peninsula and the Kodiak archipelago have typical arc geochemical signatures, with enrichment in $\mathrm{Cs}, \mathrm{Rb}, \mathrm{Ba}, \mathrm{U}, \mathrm{Sr}, \mathrm{Pb}$ and $\mathrm{K}$, and relative depletion in $\mathrm{Nb}$ and $\mathrm{Ta}$ (Figure 6). Most samples have flat to slightly LREE-enriched REE patterns, with the exception of two samples from the Alaska Peninsula, which yielded steep REE slopes that differ from the other analyses (Figure 6). Whole-rock isotopic analyses from the Alaska Peninsula plutons define a restricted range of initial values with ${ }^{143} \mathrm{Nd} /{ }^{144} \mathrm{Nd}_{\text {int }}=0.512673-0.512742\left[\varepsilon_{\mathrm{Nd}}(\mathrm{t})=5.2\right.$ to 6.6$]$ and ${ }^{87} \mathrm{Sr}^{86} \mathrm{Sr}_{\text {int }}=0.703515$ to 0.703848 (Table 3 and Figure 7). Two isotopic analyses from the Afognak pluton yielded divergent values of ${ }^{143} \mathrm{Nd} /{ }^{144} \mathrm{Nd}_{\text {int }}=0.512661\left[\varepsilon_{\mathrm{Nd}}(\mathrm{t})=5.8\right]$, ${ }^{87} \mathrm{Sr}^{86} \mathrm{Sr}_{\text {int }}=0.703947$ and ${ }^{143} \mathrm{Nd} /{ }^{144} \mathrm{Nd}_{\text {int }}=0.512826$ $\left[\varepsilon_{\mathrm{Nd}}(\mathrm{t})=9.0\right],{ }^{87} \mathrm{Sr} /{ }^{86} \mathrm{Sr}_{\mathrm{int}}=0.703730$ (Table 3 and Figure 7 ).

\section{Discussion}

\subsection{Plutonism in the Western Talkeetna Arc}

[12] Our new data record a plutonic crystallization age of $212.87 \pm 0.19 \mathrm{Ma}$ from the Afognak pluton on Kodiak Island. This high-precision CA-TIMS analysis is equivalent to an existing $\mathrm{U}-\mathrm{Pb}$ zircon age from Afognak pluton exposures in Malina bay (217 $\pm 10 \mathrm{Ma}$; Roeske et al., 1989]. The plutonic ages are also coeval with biostratigraphic ages within volcanic rocks of the overlying Shuyak Formation. The correlative ages, together with the similar arc geochemical signatures in the volcanic and plutonic rocks [Farris, 2009], supports the interpretation that the Afognak pluton represents the intrusive equivalent of Shuyak volcanism. The Late Triassic ages predate the earliest plutonic ages from the eastern exposures of the arc (Figure 8), indicating that the Kodiak section represents the earliest preserved record of Talkeetna arc magmatism. 

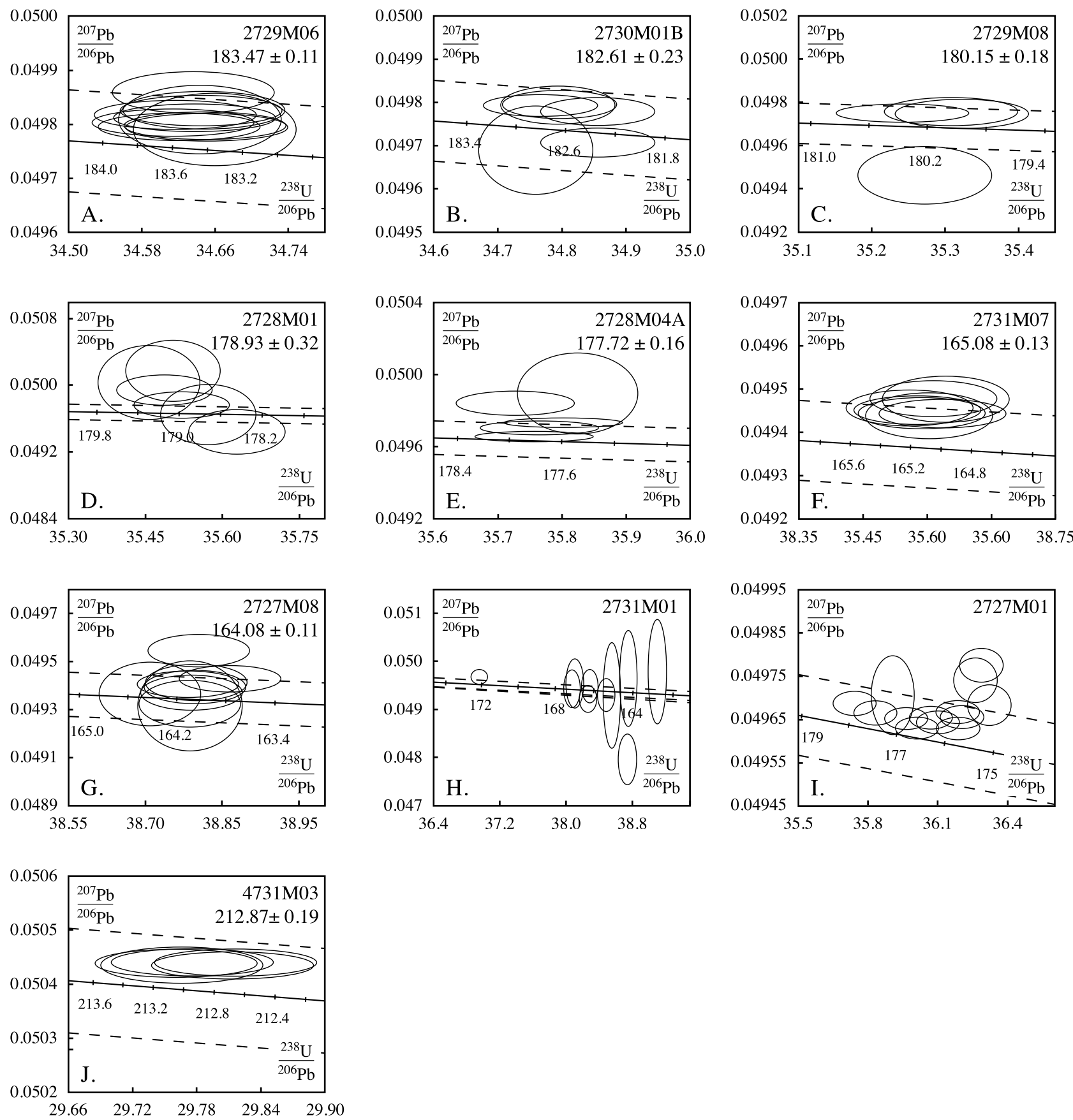

Figure 3. Tera-Wasserburg concordia plots of CA-TIMS data. The plots include only high-temperature digestion steps from multistep analyses. Reported ages are weighted mean ${ }^{206} \mathrm{~Pb} /{ }^{238} \mathrm{U}$ ages. Error ellipses and age errors are $2 \sigma$. Dashed lines show $2 \sigma$ uncertainties on concordia based on decay constant uncertainties of ${ }^{238} \mathrm{U}=0.107 \%$ and ${ }^{235} \mathrm{U}=0.136 \%$ [Jaffey et al., 1971]. All plots produced using Isoplot 3.0/ 3.2 [Ludwig, 2003]. Ages along concordia are in Ma. 

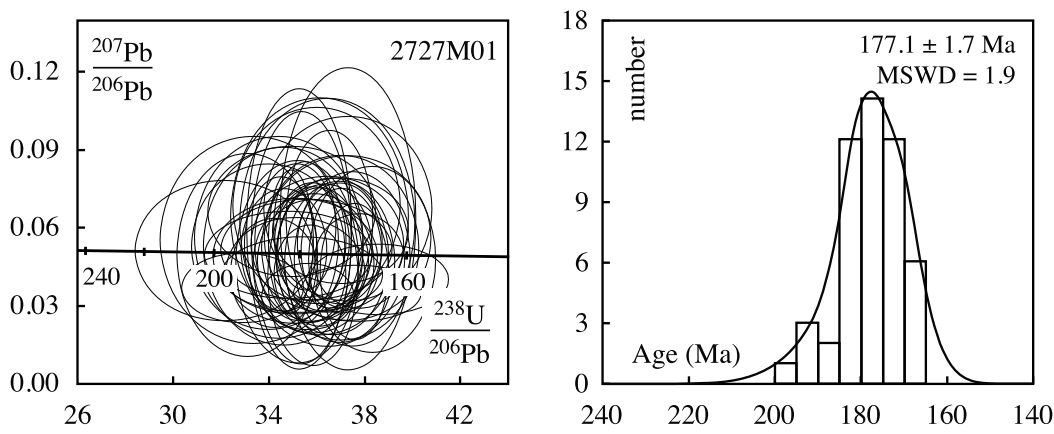

Figure 4. Tera-Wasserburg concordia plot and histogram of laser ablation-inductively coupled plasmamass spectrometry U-Pb zircon data. Plots were produced using Isoplot 3.0/3.2 [Ludwig, 2003]. Ages along concordia are in $\mathrm{Ma}$.

[13] The Jurassic batholith on the Alaska Peninsula, which parallels the strike of the Kodiak section, records distinctly younger crystallization ages of 183.47 to $164.08 \mathrm{Ma}$. A single published $\mathrm{U}-\mathrm{Pb}$ zircon age of $180 \pm 2 \mathrm{Ma}$ from a synvolcanic intrusion into Talkeetna Formation volcanic rocks in this area is coeval with the earliest plutonic dates [Millholland et al., 1987]. The data suggest a northward (present coordinates) shift in arc magmatism between formation of the Late Triassic Afognak pluton and intrusion of the Jurassic batholith (Figure 8c). The CA-TIMS and LAICP-MS data for samples 2731M01 and 2727M01 are consistent with minor inheritance of slightly older Jurassic or Late Triassic zircons and most likely reflect interaction of these magmas with older arc plutonic rocks. Similar chemical abrasion and laser ablation data were seen in plutonic analyses from the eastern and central Talkeetna Mountains [Rioux et al., 2007].

\subsection{Tectonic Development of the Talkeetna Arc}

[14] The evolution of arc magmatism on the Alaska Peninsula and Kodiak archipelago parallels the trend of magmatism in the Chugach Mountains and eastern Talkeetna Mountains (Figure 8) [Rioux et al., 2007]. Plutonic rocks from the Chugach Mountains record $\mathrm{U}-\mathrm{Pb}$ zircon ages from 202.1 to $181.4 \mathrm{Ma}$. This initial magmatism was followed by a northward shift and formation of the intermediate to felsic plutonic rocks preserved in the eastern Talkeetna Mountains between 177.5 and 168.9 Ma (Figures 8 and 9). Initial isotopic ratios from these areas range from ${ }^{143} \mathrm{Nd} /{ }^{144} \mathrm{Nd}_{\text {int }}=$ $0.512706-0.512785$ and ${ }^{87} \mathrm{Sr} /{ }^{86} \mathrm{Sr}_{\text {int }}=0.703379-0.703951$, and epsilon values are similar to data from modern arcs (Figure 7). The northward migration of the arc axis relative to the earliest arc magmatism along the entire length of the Talkeetna arc can be explained by a range of processes, including tectonic erosion of the fore arc [Clift et al., 2005b] or shallowing of the subducting slab [Plafker et al., 1989].

[15] Data from the western Talkeetna Mountains are more complex and reflect interaction between Talkeetna arc plutonic rocks and Wrangellia terrane crust [Rioux et al., 2007]. U-Pb zircon dates from the western Talkeetna Mountains record crystallization ages from 190 to $153 \mathrm{Ma}$ (Figures 8 and 9), but all the samples contain inherited xenocrystic Carboniferous-Triassic zircons and are charac- terized by relatively evolved whole-rock initial isotopic ratios $\left({ }^{143} \mathrm{Nd} /{ }^{144} \mathrm{Nd}_{\text {int }}=0.512599-0.512721\right.$ and ${ }^{87} \mathrm{Sr} /{ }^{86} \mathrm{Sr}_{\text {int }}=$ $0.703656-0.706252)$. These U-Pb zircon ages and wholerock isotopic systematics are consistent with assimilation of Wrangellia terrane crust into younger ( $190 \mathrm{Ma})$ arc magmas, with the $\sim 153$ Ma trondhjemite pluton in the central Talkeetna Mountains potentially representing a stitching pluton between the Talkeetna arc and the adjacent Wrangellia terrane [Rioux et al., 2007].

\subsection{Role of Preexisting Crust in the Formation of Silicic Talkeetna Arc Plutons}

[16] To understand the source of intermediate to felsic plutons on the Alaska Peninsula, it is critical to determine the role of preexisting crustal material in the development of the Talkeetna arc. Zircon analyses from Talkeetna Formation volcanic rocks and interplutonic screens on the Alaska Peninsula constrain the tectonic setting of the western extent of the arc. Multigrain U-Pb zircon analyses from the base of the Talkeetna Formation on the Alaska Peninsula record eruption ages of $\sim 197.8 \mathrm{Ma}$, but contain evidence for inheritance of significantly older zircon [Pálfy et al., 1999]: Discordant analyses from two of the analyzed tuffs are consistent with Middle Proterozoic $(\sim 1100 \mathrm{Ma})$ to late Archean ( 2800 Ma) upper intercept ages. Similarly, detrital zircon analyses from roof pendants within Jurassic plutonic rocks on the Alaska Peninsula yield abundant Jurassic zircons, but also contain Triassic to Archean grains [Amato et al., 2007]. These data require that the Jurassic batholith formed in close proximity to older crust or terrigenous sediment. Preserved prearc crust in the batholith consists of inferred Triassic greenstone and overlying Triassic limestone [Detterman and Reed, 1980], which may represent either pieces of Wrangellia (Nikolai) flood basalts or remnant oceanic crust that was intruded by the arc plutons.

[17] The isotopic data from the arc constrain the role of the preexisting material in the evolution of arc magmas. As discussed above, the range of initial isotopic values from the Chugach and eastern Talkeetna Mountains is similar to data from modern arcs [Rioux et al., 2007] (Figure 7), and there is no evidence for the presence of older crustal material in these areas [Amato et al., 2007]. Nine of the 11 isotopic ratios from the Alaska Peninsula and the Afognak pluton are 
Table 2. Whole-Rock Geochemical Analyses

\begin{tabular}{|c|c|c|c|c|c|c|c|c|c|c|c|}
\hline & \multicolumn{9}{|c|}{ Alaska Peninsula Samples } & \multicolumn{2}{|c|}{ Kodiak Island Samples } \\
\hline & $2727 \mathrm{M} 01$ & 2727M08 & 2728M01 & $2728 \mathrm{M} 04 \mathrm{a}$ & 2729M06 & 2729M08 & $2730 \mathrm{M} 01 \mathrm{~b}$ & $2731 \mathrm{M} 01$ & $2731 \mathrm{M} 07$ & $4731 \mathrm{M} 03$ & $7-20-\mathrm{S} 12$ \\
\hline \multicolumn{12}{|c|}{$I C P-A E S$} \\
\hline $\mathrm{SiO}_{2}$ & 64.23 & 65.77 & 61.88 & 56.25 & 70.43 & 61.87 & 53.90 & 71.38 & 47.89 & 75.80 & 59.45 \\
\hline $\mathrm{TiO}_{2}$ & 0.47 & 0.34 & 0.81 & 0.80 & 0.44 & 0.56 & 0.59 & 0.09 & 0.91 & 0.21 & 0.67 \\
\hline $\mathrm{Al}_{2} \mathrm{O}_{3}$ & 16.82 & 18.01 & 16.99 & 17.94 & 13.53 & 16.64 & 17.44 & 15.95 & 19.79 & 13.81 & 16.76 \\
\hline $\mathrm{Fe}_{2} \mathrm{O}_{3}$ & 6.12 & 3.09 & 7.09 & 8.60 & 4.67 & 6.32 & 8.97 & 1.07 & 10.05 & 2.39 & 8.19 \\
\hline $\mathrm{MnO}$ & 0.16 & 0.08 & 0.14 & 0.18 & 0.10 & 0.14 & 0.16 & 0.04 & 0.18 & 0.07 & 0.15 \\
\hline $\mathrm{MgO}$ & 2.54 & 0.86 & 2.27 & 3.28 & 1.56 & 2.70 & 4.96 & 0.31 & 4.79 & 0.54 & 3.42 \\
\hline $\mathrm{CaO}$ & 6.39 & 5.07 & 5.94 & 8.01 & 4.58 & 6.41 & 8.73 & 2.59 & 10.14 & 2.97 & 6.20 \\
\hline $\mathrm{Na}_{2} \mathrm{O}$ & 3.40 & 5.18 & 3.99 & 3.45 & 3.13 & 3.64 & 2.65 & 5.43 & 3.18 & 3.89 & 3.36 \\
\hline $\mathrm{K}_{2} \mathrm{O}$ & 0.96 & 0.77 & 1.25 & 0.85 & 0.93 & 0.34 & 0.82 & 1.25 & 0.25 & 1.39 & 1.16 \\
\hline $\mathrm{P}_{2} \mathrm{O}_{5}$ & 0.06 & 0.14 & 0.22 & 0.20 & 0.08 & 0.12 & 0.06 & 0.03 & 0.25 & 0.05 & 0.10 \\
\hline Total & 101.14 & 99.31 & 100.59 & 99.56 & 99.45 & 98.76 & 98.27 & 98.15 & 97.41 & 101.09 & 99.45 \\
\hline LOI & 0.007 & 0.008 & 0.006 & 0.008 & 0.007 & 0.012 & 0.013 & 0.012 & 0.005 & 0.010 & 0.017 \\
\hline \multicolumn{12}{|c|}{$I C P-M S$} \\
\hline $\mathrm{Li}$ & 10.5 & 12.4 & 11.7 & 8.50 & 5.79 & 4.95 & 13.1 & 3.09 & 6.30 & 8.17 & 4.67 \\
\hline $\mathrm{Be}$ & 0.570 & 0.873 & 1.25 & 0.787 & 0.563 & 0.646 & 0.509 & 0.832 & 0.581 & 0.732 & 0.703 \\
\hline $\mathrm{Sc}$ & 20.7 & 3.82 & 25.0 & 25.1 & 16.9 & 21.6 & 33.5 & 1.31 & 23.2 & 7.68 & 30.3 \\
\hline V & 140 & 55.9 & 132 & 221 & 125 & 153 & 287 & 37.6 & 260 & 30.5 & 214 \\
\hline $\mathrm{Cr}$ & 5.63 & 0.476 & 9.85 & 12.0 & 3.51 & 6.22 & 27.1 & 0.223 & 23.6 & 1.25 & 7.37 \\
\hline Co & 13.1 & 4.49 & 12.5 & 17.7 & 10.6 & 15.3 & 28.9 & 1.33 & 26.8 & 3.38 & 23.3 \\
\hline $\mathrm{Ni}$ & 6.77 & 4.27 & 8.01 & 6.50 & 5.62 & 6.17 & 13.9 & 2.83 & 22.7 & 2.63 & 7.89 \\
\hline $\mathrm{Cu}$ & 3.46 & 3.08 & 10.9 & 20.4 & 14.3 & 15.6 & 42.5 & 1.08 & 27.4 & 2.08 & 56.7 \\
\hline $\mathrm{Zn}$ & 57.0 & 55.0 & 79.3 & 77.5 & 51.1 & 49.3 & 75.2 & 28.2 & 99.9 & 30.4 & 71.5 \\
\hline $\mathrm{Rb}$ & 18.4 & 12.2 & 29.5 & 19.3 & 16.9 & 5.61 & 17.8 & 17.8 & 2.08 & 16.8 & 20.4 \\
\hline $\mathrm{Sr}$ & 241 & 673 & 316 & 342 & 148 & 299 & 210 & 524 & 581 & 180 & 279 \\
\hline $\mathrm{Y}$ & 20.9 & 7.06 & 49.3 & 17.4 & 22.0 & 19.1 & 17.6 & 3.14 & 12.8 & 14.6 & 35.0 \\
\hline $\mathrm{Zr}$ & 44.0 & 69.8 & 244 & 77.0 & 123 & 75.8 & 44.6 & 57.5 & 21.8 & 86.2 & 203 \\
\hline $\mathrm{Nb}$ & 1.45 & 1.99 & 4.40 & 2.60 & 1.51 & 1.33 & 1.13 & 1.50 & 2.51 & 2.60 & 3.43 \\
\hline Cs & 0.863 & 0.433 & 0.888 & 0.750 & 0.642 & 0.572 & 0.699 & 0.349 & 0.142 & 2.39 & 1.23 \\
\hline $\mathrm{Ba}$ & 416 & 478 & 846 & 426 & 458 & 308 & 207 & 790 & 130 & 477 & 391 \\
\hline $\mathrm{La}$ & 6.26 & 27.5 & 17.0 & 9.77 & 5.74 & 5.60 & 3.64 & 2.91 & 5.70 & 10.7 & 8.47 \\
\hline $\mathrm{Ce}$ & 15.2 & 55.9 & 40.0 & 21.5 & 13.7 & 12.7 & 8.70 & 6.76 & 14.4 & 21.1 & 22.3 \\
\hline $\operatorname{Pr}$ & 2.10 & 6.63 & 5.76 & 2.68 & 1.82 & 1.73 & 1.20 & 0.808 & 2.09 & 2.41 & 3.23 \\
\hline $\mathrm{Nd}$ & 9.57 & 23.6 & 26.3 & 11.2 & 8.26 & 8.00 & 5.72 & 3.23 & 10.1 & 9.23 & 15.07 \\
\hline $\mathrm{Sm}$ & 2.59 & 3.02 & 7.06 & 2.56 & 2.28 & 2.22 & 1.72 & 0.599 & 2.49 & 1.96 & 4.30 \\
\hline $\mathrm{Eu}$ & 0.740 & 0.728 & 1.70 & 1.08 & 0.721 & 0.896 & 0.585 & 0.296 & 0.97 & 0.546 & 0.982 \\
\hline $\mathrm{Gd}$ & 3.00 & 2.10 & 7.98 & 2.74 & 2.81 & 2.76 & 2.25 & 0.505 & 2.54 & 2.00 & 5.00 \\
\hline $\mathrm{Tb}$ & 0.515 & 0.289 & 1.36 & 0.454 & 0.494 & 0.477 & 0.403 & 0.0761 & 0.396 & 0.337 & 0.869 \\
\hline Dy & 3.32 & 1.25 & 8.52 & 2.81 & 3.27 & 3.10 & 2.69 & 0.431 & 2.28 & 2.11 & 5.66 \\
\hline Ho & 0.726 & 0.242 & 1.83 & 0.615 & 0.723 & 0.680 & 0.582 & 0.0942 & 0.464 & 0.473 & 1.23 \\
\hline $\mathrm{Er}$ & 2.10 & 0.694 & 5.20 & 1.80 & 2.15 & 1.95 & 1.70 & 0.285 & 1.26 & 1.43 & 3.49 \\
\hline $\mathrm{Yb}$ & 2.18 & 0.617 & 5.04 & 1.94 & 2.31 & 2.00 & 1.77 & 0.347 & 1.20 & 1.64 & 3.50 \\
\hline $\mathrm{Lu}$ & 0.348 & 0.100 & 0.776 & 0.320 & 0.375 & 0.325 & 0.281 & 0.0603 & 0.188 & 0.278 & 0.547 \\
\hline $\mathrm{Hf}$ & 1.41 & 1.92 & 6.30 & 2.04 & 3.09 & 1.98 & 1.35 & 1.51 & 0.841 & 2.02 & 4.74 \\
\hline $\mathrm{Ta}$ & 0.118 & 0.0857 & 0.293 & 0.184 & 0.125 & 0.105 & 0.111 & 0.097 & 0.114 & 0.191 & 0.236 \\
\hline $\mathrm{Pb}$ & 3.76 & 3.40 & 4.46 & 3.92 & 3.04 & 2.44 & 1.37 & 6.48 & 2.28 & 2.73 & 2.52 \\
\hline Th & 0.888 & 2.47 & 3.34 & 2.96 & 1.51 & 0.938 & 1.03 & 0.301 & 0.299 & 2.20 & 1.14 \\
\hline U & 0.356 & 0.292 & 1.11 & 1.22 & 0.794 & 0.453 & 0.512 & 0.104 & 0.232 & 1.85 & 0.630 \\
\hline
\end{tabular}

comparable to those determined from the Chugach and eastern Talkeetna Mountains, suggesting that there was little or no assimilation of isotopically evolved older crust into these plutons. One datum from the peninsula, and one from the Afognak pluton, have slightly lower ${ }^{143} \mathrm{Nd} /{ }^{144} \mathrm{Nd}_{\text {int }}$ ratios, which may reflect variations in the source composition or assimilation of material with a lower ${ }^{143} \mathrm{Nd} /{ }^{144} \mathrm{Nd}_{\text {int }}$. However, the restricted range of the isotopic data from these areas, the absence of pre-Mesozoic inherited zircon in the plutonic samples, and the very limited extent of preserved prearc crust suggests that there was a restricted volume of any older crustal component and that it had little or no impact on the geochemical evolution of most of the arc plutons. The data indicate that the Talkeetna arc, which is exposed over an area that is comparable to the extensive Sierra Nevada batholith, California, represents a major addition of juvenile crust onto the continental margin.

\subsection{Felsic Magmatism in Intraoceanic Arcs}

[18] The four major exposures of the Talkeetna arc all contain varying proportions of intermediate to felsic plutons. The crustal section in the Chugach Mountains is dominated by ultramafic to mafic lithologies, but preserves a layer of more evolved plutons in the middle crust directly below the volcanic section (Figure 8). In contrast, the Talkeetna 

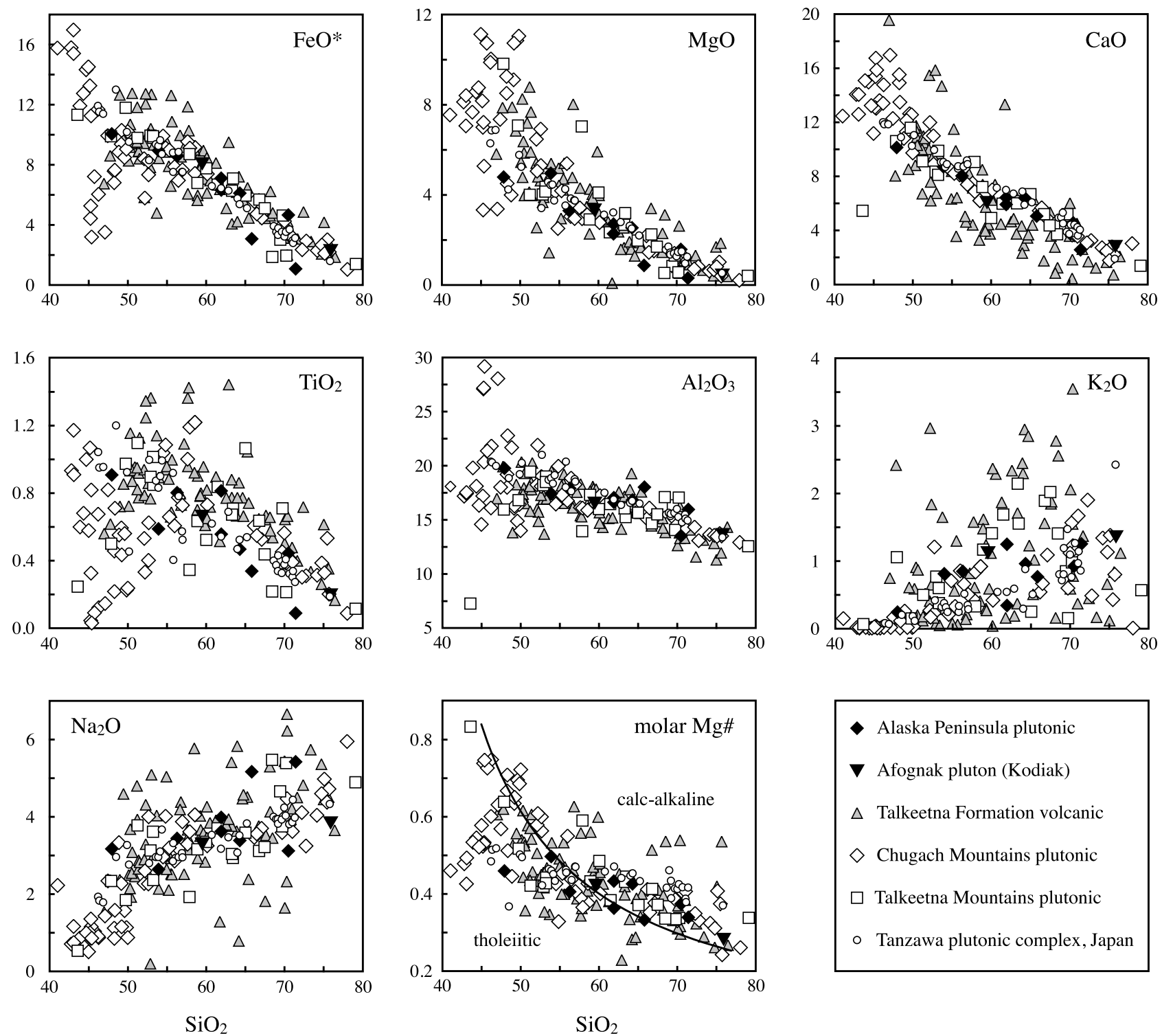

Figure 5. Whole-rock major element variation diagrams for the Jurassic plutonic rocks on the Alaska Peninsula and the Kodiak archipelago. Data from plutonic rocks from the Chugach and Talkeetna Mountains [Greene et al., 2006; Rioux, 2006] and volcanic rocks of the Talkeetna Formation from the Chugach and Talkeetna Mountains [Clift et al., 2005a] are included for comparison. The Chugach Mountains plutonic rocks include cumulate compositions [Greene et al., 2006]. The calc-alkaline and tholeiitic fields are after Miyashiro [1974].

Mountains and Alaska Peninsula consist of large intermediate to felsic batholiths, with only limited mafic material (Figures 2 and 8): the samples from the Alaska Peninsula analyzed in this study range from 48 to 76 wt $\% \mathrm{SiO}_{2}$, but the lower silica sample is not representative of the main volume of plutonic rocks. The limited exposures of plutonic rocks on the Kodiak archipelago contain dioritic to tonalitic plutons in faulted contacted with mafic and ultramafic lithologies (Figure 2). The relative proportions of evolved plutons are likely structurally controlled. The crustal sections in the Chugach Mountains and on the Kodiak archipelago are composed of steeply dipping plutonic and volcanic blocks
[Connelly and Moore, 1979; Winkler, 1992], leading to thin, faulted layers of evolved midcrustal material. In contrast, some volcanic rocks on the Alaska Peninsula and in the Talkeetna Mountains have shallow to flat dips [Csejtey et al., 1978; Detterman and Reed, 1980], suggesting that these areas represent broad slices through midcrustal plutonic complexes. All of the plutonic sections define similar geochemical trends (Figures 5 and 6), and the evolved crust in these areas is chemically similar to the middle crust of the Izu-Bonin arc exposed in the Tanzawa plutonic complex (Figures 5 and 6). 

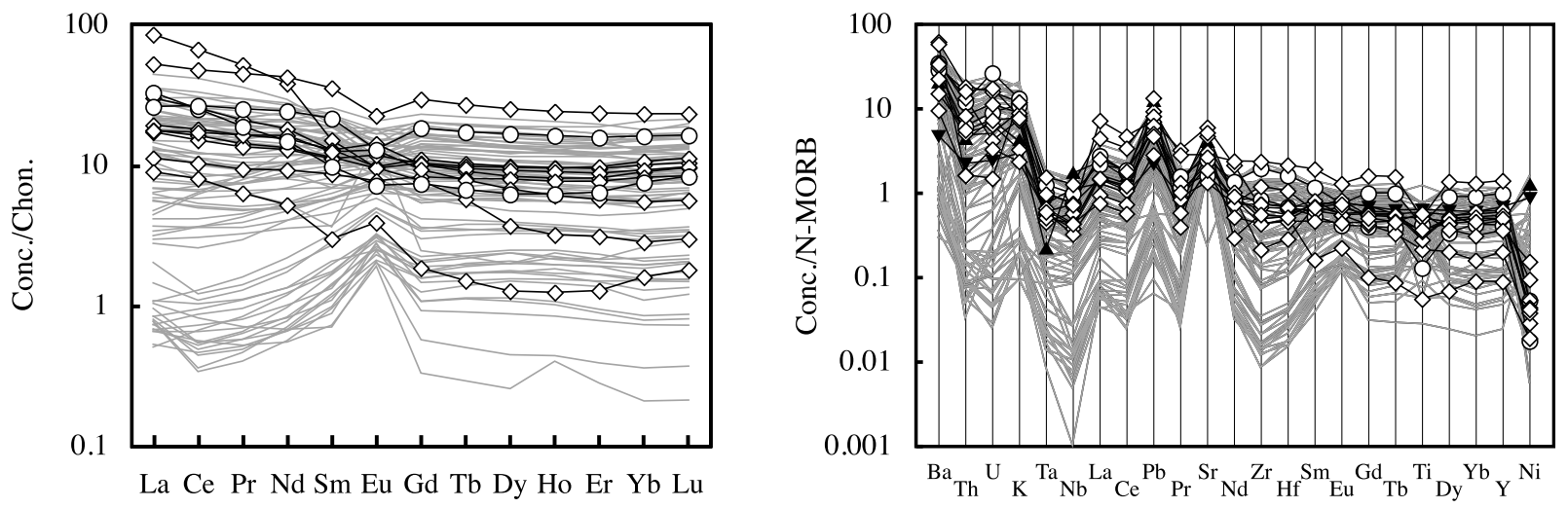

Figure 6. Rare earth element and trace element variation diagrams of the Alaska Peninsula (diamonds) and Afognak pluton (circles) samples. Data from plutonic and chilled mafic dikes from the Chugach and eastern Talkeetna Mountains are shown in gray for comparison [Greene et al., 2006; Rioux, 2006 ]. Average primitive arc basalts from the Tonga (triangles) and Mariana (inverted triangles) arcs are included in the trace element variation diagram [Kelemen et al., 2003a]. The rare earth element patterns are chondrite normalized [Nakamura, 1974], and the trace element patterns are normalized to NMORB [Hofmann, 1988].

[19] The major element trends of the Talkeetna data are consistent with the intermediate to felsic plutonic and volcanic rocks forming by fractionation of mantle derived basaltic magmas. Greene et al. [2006] used least squares modeling to demonstrate that Talkeetna arc volcanic rocks with up to $57 \mathrm{wt} \% \mathrm{SiO}_{2}$ can be generated from mantle derived basalts by fractional crystallization of cumulate mineral compositions preserved in exposed lower crustal pyroxenites and gabbronorites in the Chugach Mountains. Johnsen [2007] and Johnsen et al. [2007] built on this work to show that the range of plutonic compositions from the Alaska Peninsula can be explained by further fractional crystallization of intermediate composition magmas, combined with variable degrees of magma mixing. The trace element data from the arc are generally consistent with the mafic plutonic rocks preserved in the Chugach section representing the cumulate fractionates of the more evolved plutonic and volcanic rocks: high $\mathrm{Eu} / \mathrm{Sm}$ and $\mathrm{Ti} / \mathrm{Dy}$ or $\mathrm{Ti} / \mathrm{Yb}$ in lower crustal gabbronorites are matched by progressively lower $\mathrm{Eu} / \mathrm{Sm}$ and $\mathrm{Ti} / \mathrm{Dy}$ or $\mathrm{Ti} / \mathrm{Yb}$ in most intermediate to felsic volcanic and plutonic rocks $\left(>60 \mathrm{wt} \% \mathrm{SiO}_{2}\right)$ from the Chugach Mountains, the Talkeetna Mountains and the Alaska Peninsula, likely reflecting plagioclase and magnetite fractionation [Kelemen et al., 2003a; Clift et al., 2005a; Greene et al., 2006; Rioux, 2006; this study].

[20] Calculated seismic velocities of the silicic Talkeetna arc plutonic rocks allow for direct comparison to seismic profiles of modern arcs (Table 4). P and $\mathrm{S}$ wave velocities were calculated from thermodynamic parameters and third order finite strain theory using the Excel macro developed by Hacker and Abers [2004] with an updated database. Modal mineralogies were determined by thin section point

Table 3. Sm-Nd and Rb-Sr Data From the Jurassic Plutons on the Alaska Peninsula

\begin{tabular}{|c|c|c|c|c|c|c|c|c|c|c|c|c|c|c|c|}
\hline Sample & $\mathrm{Sm}$ & $\mathrm{Nd}$ & $\frac{{ }^{147} \mathrm{Sm}}{{ }^{144} \mathrm{Nd}}$ & $\frac{{ }^{143} \mathrm{Nd}}{{ }^{144} \mathrm{Nd}}$ & $2 \sigma^{\mathrm{a}}$ & ${ }^{1443} \mathrm{Nd}$ dint & $\varepsilon_{\mathrm{Nd}}(\mathrm{t})^{\mathrm{b}}$ & $\mathrm{Rb}$ & $\mathrm{Sr}$ & $\frac{{ }^{87} \mathrm{Rb}}{{ }^{86} \mathrm{Sr}}$ & $\frac{87 \mathrm{Sr}}{86 \mathrm{Sr}}$ & $2 \sigma^{\mathrm{a}}$ & ${ }^{\frac{87}{86} \mathrm{Sr}}$ & $\varepsilon_{\mathrm{Sr}}(\mathrm{t})^{\mathrm{b}}$ & $\operatorname{Age}^{\mathrm{c}}(\mathrm{Ma})$ \\
\hline \multicolumn{16}{|c|}{ Alaska Peninsula } \\
\hline 2727M01 & 2.6 & 9.5 & 0.167 & 0.512910 & (36) & 0.512719 & 6.0 & 17.2 & 230.4 & 0.216 & 0.704147 & (14) & 0.703609 & -9.8 & 175 \\
\hline 2727M08 & 3.0 & 22.5 & 0.080 & 0.512807 & (11) & 0.512721 & 5.7 & 11.2 & 633.7 & 0.051 & 0.703672 & (19) & 0.703553 & -10.8 & 164.1 \\
\hline 2728M01 & 7.2 & 26.4 & 0.165 & 0.512893 & (9) & 0.512700 & 5.7 & 27.6 & 310.4 & 0.258 & 0.704170 & (21) & 0.703515 & -11.0 & 178.9 \\
\hline $2728 \mathrm{M} 04 \mathrm{~A}$ & 2.6 & 11.3 & 0.141 & 0.512837 & (16) & 0.512673 & 5.2 & 17.8 & 339.4 & 0.152 & 0.704177 & (19) & 0.703793 & -7.1 & 177.7 \\
\hline 2729M06 & 2.4 & 8.5 & 0.169 & 0.512916 & (24) & 0.512713 & 6.1 & 15.8 & 140.1 & 0.326 & 0.704376 & (14) & 0.703524 & -10.8 & 183.5 \\
\hline 2729M08 & 2.2 & 7.9 & 0.171 & 0.512913 & (16) & 0.512712 & 6.0 & 5.4 & 286.7 & 0.054 & 0.703987 & (18) & 0.703848 & -6.3 & 180.2 \\
\hline 2730M01B & 1.8 & 5.8 & 0.190 & 0.512969 & (18) & 0.512742 & 6.6 & 16.2 & 202.3 & 0.231 & 0.704325 & (16) & 0.703724 & -8.0 & 182.6 \\
\hline 2731M01 & 0.6 & 3.3 & 0.111 & 0.512847 & (24) & 0.512727 & 5.9 & 16.5 & 501.9 & 0.095 & 0.703847 & (16) & 0.703625 & -9.7 & 164 \\
\hline 2731M07 & 2.5 & 10.0 & 0.155 & 0.512880 & (38) & 0.512713 & 5.6 & 2.1 & 576.8 & 0.010 & 0.703781 & (14) & 0.703757 & -7.8 & 165.1 \\
\hline \multicolumn{16}{|c|}{ Kodiak Archipelago } \\
\hline 4731M03 & 2.0 & 9.3 & 0.128 & 0.512839 & (20) & 0.512661 & 5.8 & 15.5 & 170.8 & 0.263 & 0.704743 & (21) & 0.703947 & -4.3 & 212.9 \\
\hline $7-20-S 12$ & 4.3 & 15.1 & 0.174 & 0.513068 & (14) & 0.512826 & 9.0 & 18.7 & 274.3 & 0.198 & 0.704329 & (14) & 0.703730 & -7.4 & 213 \\
\hline
\end{tabular}

${ }^{a}$ Absolute errors (2-sigma); reported values are in units of $10^{-6}$

${ }^{\mathrm{b}} \mathrm{All} \varepsilon_{\mathrm{Nd}}(\mathrm{t})$ and ${ }^{143} \mathrm{Nd} /{ }^{144} \mathrm{Nd}_{\text {int }}$ were calculated using present-day bulk earth values of ${ }^{143} \mathrm{Nd} /{ }^{144} \mathrm{Nd}=0.512638$ and ${ }^{147} \mathrm{Sm} /{ }^{144} \mathrm{Nd}=0.1967$, and a ${ }^{147} \mathrm{Sm}$ decay constant of $6.54 \times 10^{-12} \mathrm{yr}^{-1} ; \varepsilon_{\mathrm{Sr}}(\mathrm{t})$ and ${ }^{87} \mathrm{Sr}{ }^{86} \mathrm{Sr}_{\text {int }}$ were calculated using present-day bulk earth values of ${ }^{87} \mathrm{Sr} /{ }^{86} \mathrm{Sr}=0.7045$ and ${ }^{87} \mathrm{Rb} /{ }^{86} \mathrm{Sr}=$ 0.0816 , and an ${ }^{87} \mathrm{Rb}$ decay constant of $1.42 \times 10^{-11} \mathrm{yr}^{-1}$.

${ }^{\mathrm{c}} \mathrm{U}-\mathrm{Pb}$ zircon ages used for calculating the epsilon and initial isotopic values. Ages with no decimal are estimated from variable $\mathrm{U}-\mathrm{Pb}$ data $(2727 \mathrm{M} 01$ and $2731 \mathrm{M} 01)$ or a nearby date (7-20-S12). 

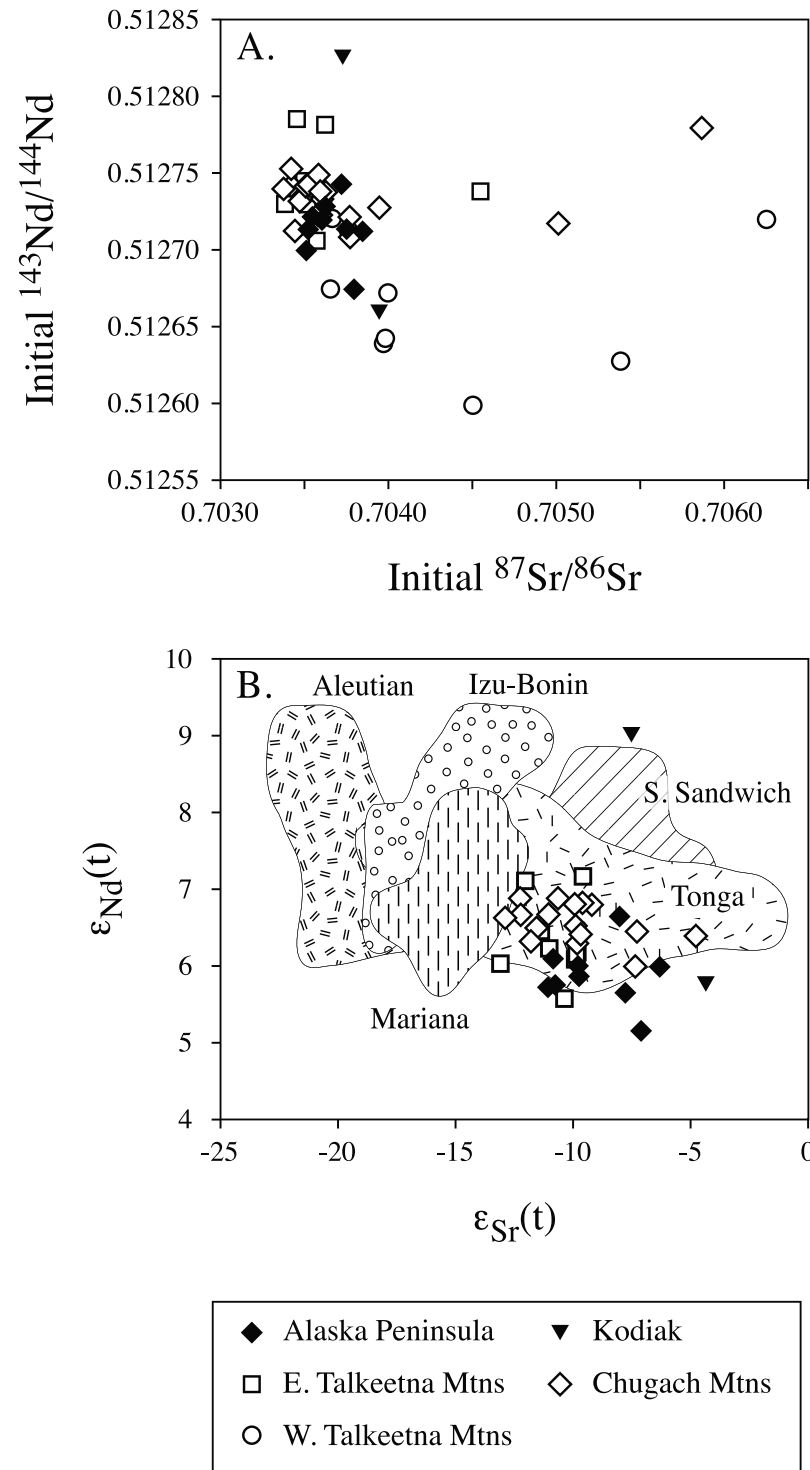

Figure 7. Radiogenic isotope data from Talkeetna arc plutonic rocks analyzed in this study and by Rioux et al. [2007]. Modern arc fields based on data from McCulloch and Perfit [1981], Ewart and Hawkesworth [1987], Woodhead [1989], Pearce et al. [1995], Ewart et al. [1998], Taylor and Nesbitt [1998], and Leat et al. [2003] were recalculated to be consistent with the standard and normalization values in this study. The Tonga-Kermadec field excludes data from the northern Tonga islands. All initial values were calculated using the parameters described in Table 3 (modified from Rioux et al., 2007]).

counts (Table S1) and mineral compositions were measured by electron microprobe [Johnsen, 2007; Hacker et al., 2008; M. E. Rioux, unpublished data, 2004) or estimated based on compositional trends from other Talkeetna plutonic rocks (data from Greene et al. [2006] and Hacker et al. [2008]). Estimated uncertainties in the plagioclase and biotite compositions lead to small $(0.04-0.1 \mathrm{~km} / \mathrm{s})$ variations in the predicted seismic velocities. Pressure and temperature were estimated from the inferred position of the silicic plutons in the Talkeetna section and data from modern arcs. Hacker et al. [2008] calculated pressures of 0.13-0.27 GPa for four tonalite and quartz diorite samples from the Chugach section, consistent with an estimated $\sim 7 \mathrm{~km}$ thickness for the overlying volcanic section [Clift et al., 2005a], and the $\sim 5-$ $12 \mathrm{~km}$ depth of low-velocity $\left(\mathrm{V}_{\mathrm{p}}=6.0-6.5 \mathrm{~km} / \mathrm{s}\right)$ zones in modern arcs [Suyehiro et al., 1996; Kodaira et al., 2007a, 2007b; Takahashi et al., 2007; Calvert et al., 2008]. Proposed temperatures at these depths in modern arcs range from 100 to $700^{\circ} \mathrm{C}$ [Kelemen et al., 2003b]. Calculated $V_{p}$ of quartz bearing plutonic rocks from the Alaska Peninsula, the Chugach Mountains and the Talkeetna Mountains range from 5.96 to $6.55 \mathrm{~km} / \mathrm{s}$ for pressures of 0.1 to $0.5 \mathrm{GPa}$ and temperatures of $100-700^{\circ} \mathrm{C}$ (Table 4). The $\mathrm{V}_{\mathrm{p}}$ decrease with increasing temperature from 100 to $600^{\circ} \mathrm{C}$ and then increase from 600 to $700^{\circ} \mathrm{C}$, reflecting changes in the elastic parameters of quartz near the $\alpha-\beta$ transition [Ohno et al., 2006]. The calculated velocities agree with previous work by Behn and Kelemen [2006], which determined $\mathrm{V}_{\mathrm{p}}=6.0$ $6.5 \mathrm{~km} / \mathrm{s}$ for Chugach Mountain plutonic rocks with $>56 \mathrm{wt}$ $\% \mathrm{SiO}_{2}$ based on thermodynamically determined equilibrium mineral assemblages $\left(0.5 \mathrm{GPa}, 475^{\circ} \mathrm{C}\right)$. The range of calculated seismic velocities are also indistinguishable from the low-velocity layers in the Izu-Bonin-Mariana, TongaKermadec and South Sandwich arcs (Figure 10).

[21] The equivalent seismic velocities, whole-rock geochemical data and restricted range in isotopic data suggest that the evolved Talkeetna arc plutons represent an analogue for low-velocity middle crust in modern arcs. As such, the data presented here, combined with existing data from Rioux et al. [2007], provide new insights into the temporal evolution of the low-velocity crust. The U-Pb zircon ages from the arc record $\sim 60 \mathrm{Ma}$ of arc magmatism from 213 to $153 \mathrm{Ma}$. The data are biased toward intermediate to felsic lithologies, which have higher $\mathrm{Zr}$ contents and more abundant zircon, and there are only limited radiometric constraints on the relative timing of mafic magmatism. However, the Talkeetna Formation volcanic rocks contain Sinemurian to Toarcian ammonites (196.5-175.6 Ma [Grantz et al., 1963; Ogg, 2004a]) and are bound by ammonite bearing Hettangian and Bajocian sedimentary units (199.6-167.7 Ma; Figure 9) [Imlay, 1984; Pálfy et al., 1999; Ogg, 2004a]). U-Pb zircon ages from the Alaska Peninsula further constrain the base of the Talkeetna Formation between $200.8 \pm 2.8 \mathrm{Ma}$ and $197.8 \pm 1.0 \mathrm{Ma}$ [Pálfy et al., 1999]. Shuyak Formation volcanic rocks on the Kodiak archipelago contain early to middle Norian pelecypods (216.5-205.7 Ma [Connelly, 1978; Ogg, 2004b]), consistent with the older plutonic ages from this section. Finally, the Naknek Formation in the Talkeetna Mountains contains evidence for active unroofing of arc volcanic and plutonic rocks from the early Oxfordian to early Tithonian (161.2 147.2 [Ogg, 2004a; Trop et al., 2005]) and provides an absolute minimum age for the termination of arc magmatism. The range in $\mathrm{U}-\mathrm{Pb}$ zircon ages from the Talkeetna plutons is equivalent to or longer than the duration of arc volcanism (Figure 9), indicating that silicic magmas were generated throughout the lifespan of the arc. In addition, the distribution of ages suggests that the evolved magmas were 

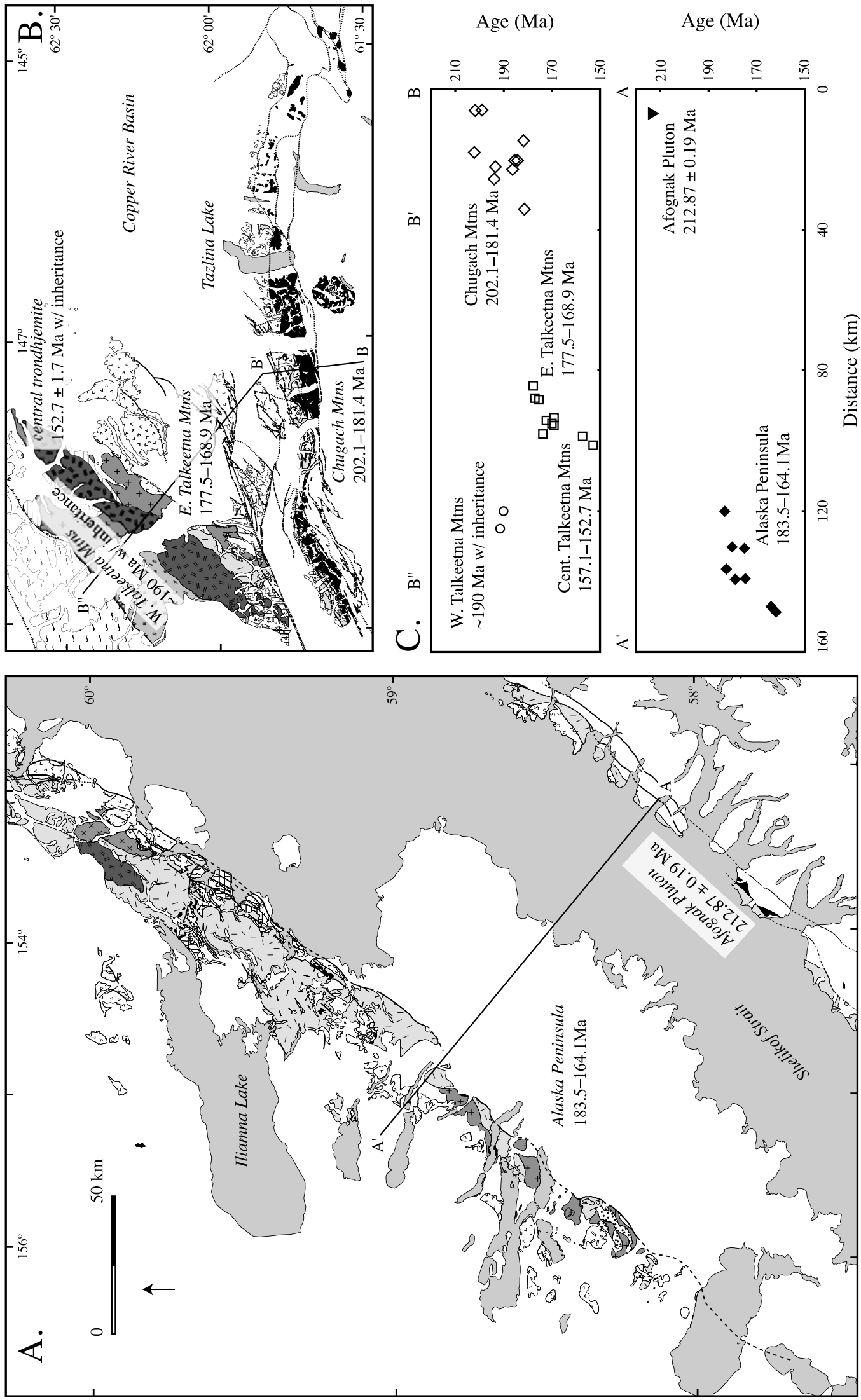

竞 


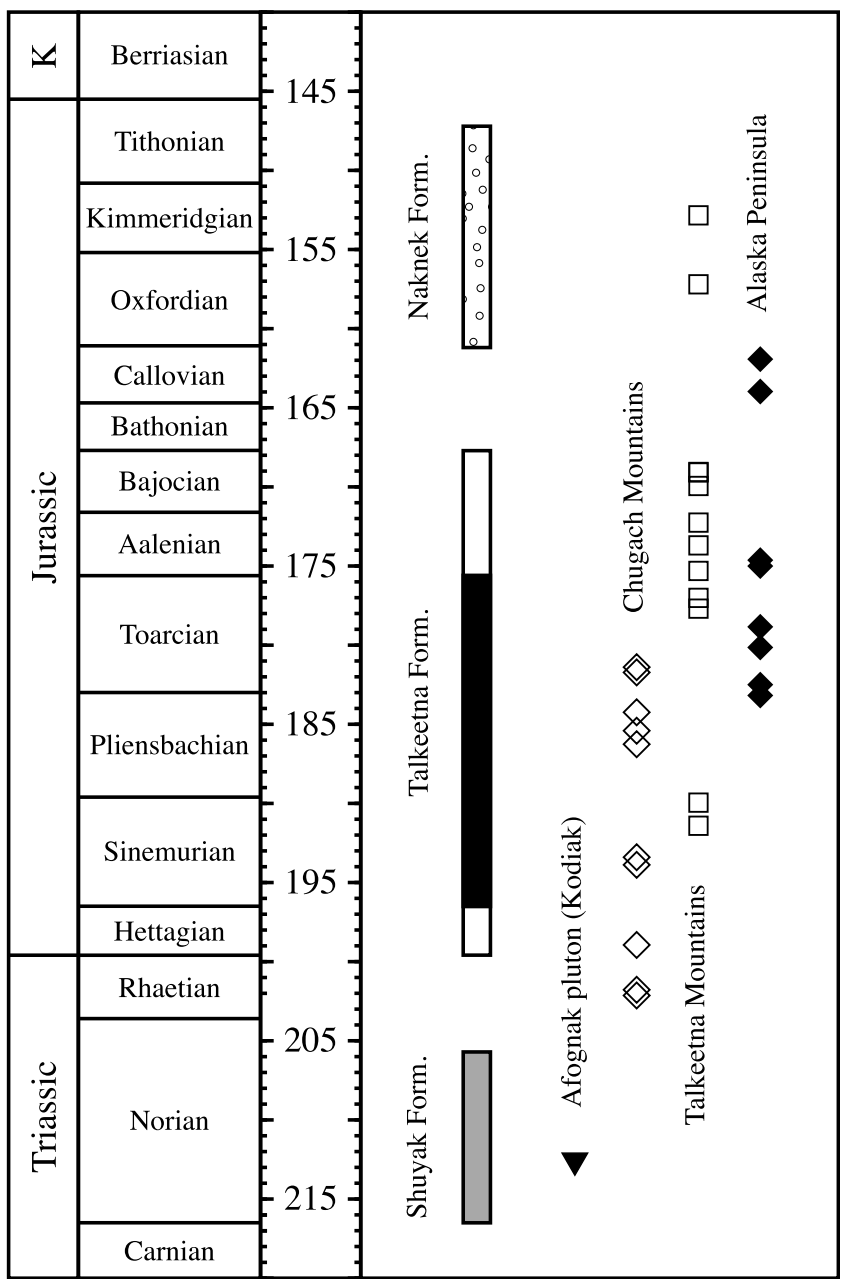

Figure 9. Time scale of Talkeetna arc volcanism and plutonism. The solid black bar shows the range of biostratigraphic ages within the Talkeetna Formation volcanic rocks [Grantz et al., 1963], and the extended white bar is the maximum possible duration of Talkeetna volcanism permitted by bounding sedimentary sequences [Imlay, 1984; Pálfy et al., 1999]. Talkeetna and Chugach Mountains zircon ages are from Rioux et al. [2007]. The spans of biostratigraphic ages from the Shuyak and Naknek Formations are from Connelly [1978] and Trop et al. [2005]. The time scale is after Ogg [2004a, 2004b].

generated by a repetitive or continuous process rather than punctuated events.

[22] Existing constraints on the temporal evolution of evolved arc magmas come from the volcanic record and seismic profiles of modern arcs. Tephra glass studies from the Mariana arc demonstrate that felsic liquids have been incorporated into erupted volcanic material throughout the duration of arc volcanism [Lee et al., 1995], although the abundance of evolved compositions in the tephra glasses is not seen in the whole-rock volcanic record and may reflect shallow level processes or small melt fractions. Seismic tomography from the Mariana arc indicates that there is well developed low-velocity middle crust in the Eocene arc, but only limited low-velocity material observed in the $<4 \mathrm{Ma}$

Figure 8. Comparison of plutonic crystallization ages from the eastern and western exposures of the Talkeetna arc. (a) Geologic map of the western Talkeetna arc on the Alaska Peninsula and Kodiak archipelago, with a summary of the U-Pb zircon ages presented herein. (b) Geologic map of the eastern Talkeetna arc in the Chugach and Talkeetna Mountains, including $\mathrm{U}-\mathrm{Pb}$ zircon ages from Rioux et al. [2007]. The scale is the same in Figures $8 \mathrm{a}$ and $8 \mathrm{~b}$. (c) Distance versus age plots for the eastern and western Talkeetna arc showing the similar temporal evolution between the two areas. The distances (km) are along the lines marked $\mathrm{A}-\mathrm{A}^{\prime}$ and $\mathrm{B}-\mathrm{B}^{\prime \prime}$. Ages are zircon ${ }^{206} \mathrm{~Pb} /{ }^{238} \mathrm{U}$ dates; for samples that generated a spread of data along concordia, the youngest high-temperature digestion step was used. Age errors are smaller than the plot symbols. The locations of Figures 8a and $8 \mathrm{~b}$ are shown in Figure 1, and the rock types follow the legend in Figure 2. The geologic maps are modified from Csejtey et al. [1978], Winkler et al. [1981], Winkler [1992], Wilson et al. [1998], and the reference given in Figure 2. 


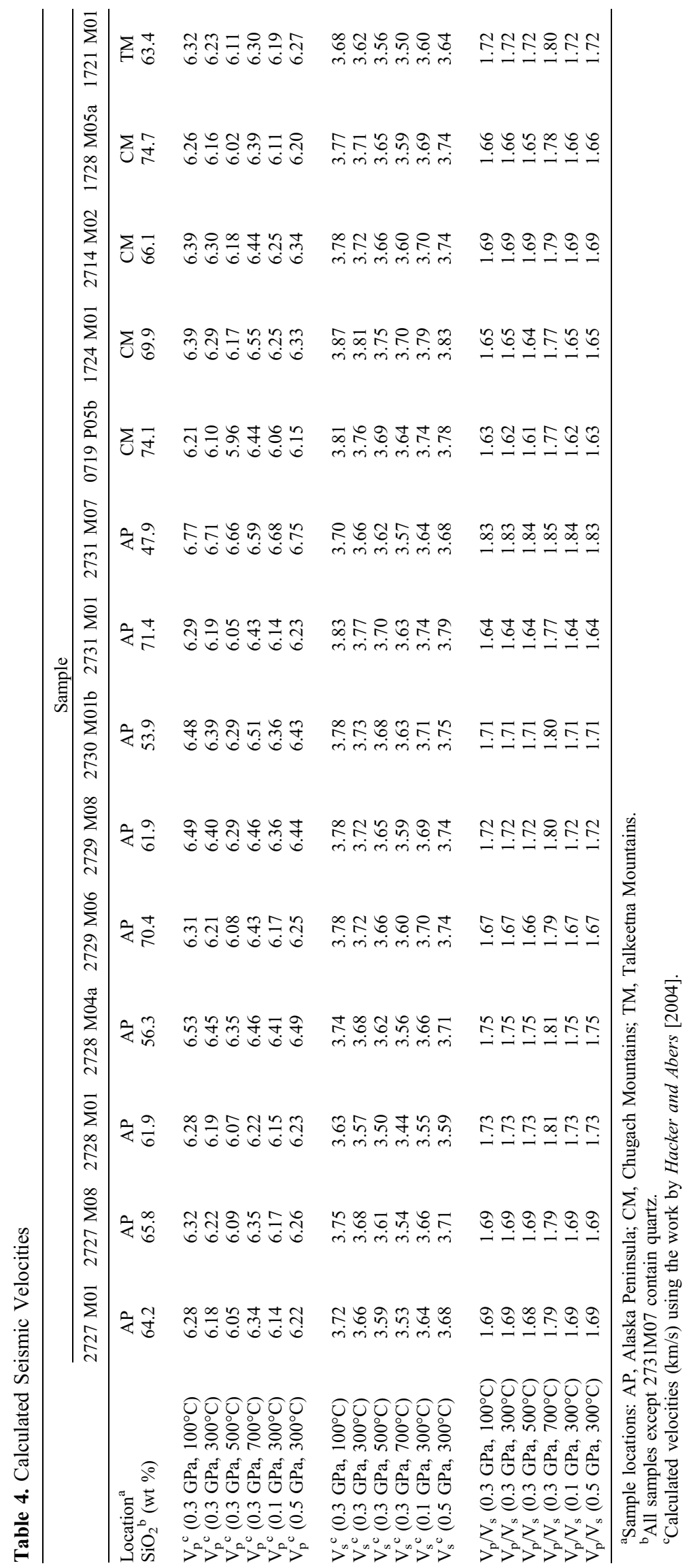

14 of 17 


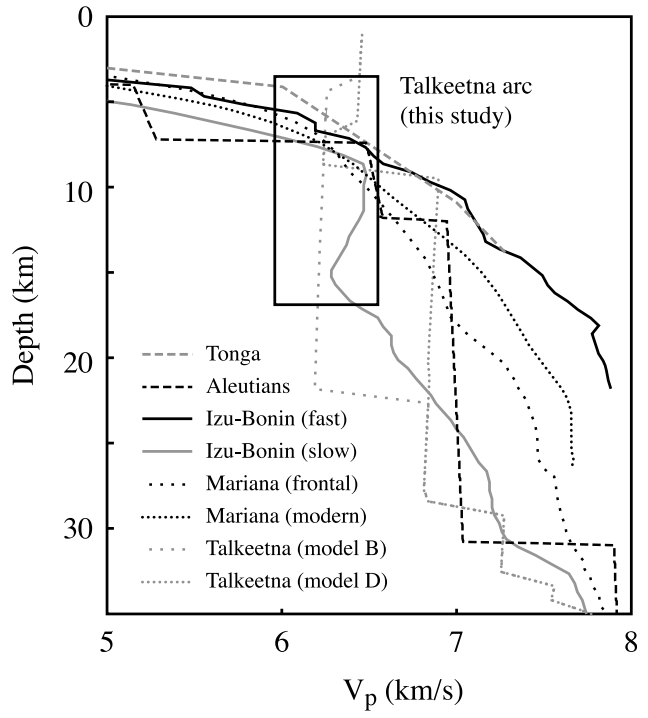

Figure 10. Comparison of observed velocity-depth profiles from modern arcs and the field of calculated $V_{p}$ of quartz bearing plutonic rocks from the Talkeetna arc (rectangle). The depth dimension of the Talkeetna arc field reflects the range of pressures used in the calculations presented in Table 4. The calculated $V_{p}$ from quartz-bearing rocks from the Talkeetna arc are consistent with midcrustal velocities from the Izu-Bonin, Tonga, and Mariana arcs. A similar $6.0-6.5 \mathrm{~km} / \mathrm{s}$ velocity middle crust is not observed in the Aleutian data [Holbrook et al., 1999]. The data from modern arcs are from Holbrook et al. [1999] (Aleutians), Crawford et al. [2003] (Tonga), Kodaira et al. [2007a] (IzuBonin), and Calvert et al. [2008] (Mariana). Talkeetna models $\mathrm{B}$ and $\mathrm{D}$ are velocity-depth profiles from the Talkeetna arc calculated using thermodynamically determined equilibrium mineral assemblages [Behn and Kelemen, 2006] for end-member crustal compositions [Hacker et al., 2006b; Kelemen et al., 2006]. For the Talkeetna arc data from this study and Behn and Kelemen [2006], pressure was converted to depth assuming a density of $2.7 \mathrm{~g} / \mathrm{cm}^{3}$ for the top $7 \mathrm{~km}$ (volcanic) and a density of $3.1 \mathrm{~g} / \mathrm{cm}^{3}$ below that.

modern arc [Calvert et al., 2008]. This observation was interpreted to reflect the temporal evolution of arc crust, where low-velocity middle crust is generated by extended anatexis and intracrustal differentiation and is restricted to mature arcs. In contrast, the $\mathrm{U}-\mathrm{Pb}$ zircon data from the Talkeetna arc indicate that intermediate to felsic magmas were generated throughout the lifespan of the arc by continuous differentiation of arc magmas or anatexis of earlier intrusions. This temporal record, along with the consistent exposure of silicic plutons along the entire $\sim 1000 \mathrm{~km}$ length of Talkeetna arc, indicate that evolved magmas are a fundamental component of the growth and evolution of arc crust.

\section{Conclusions}

[23] The U-Pb zircon ages, isotopic analyses and geochemical data from the Kodiak archipelago and the Alaska
Peninsula, together with recent research from the Chugach and Talkeetna Mountains, provide a detailed history of the tectonic and geochemical evolution of the Talkeetna arc. The geographic distribution of zircon ages indicates that initial arc magmatism was concentrated in the plutonic and volcanic sections preserved on Kodiak Island $(212.87 \pm 0.19 \mathrm{Ma})$ and in the Chugach Mountains (201.5-180.4 Ma). The arc axis subsequently shifted northward, generating the large plutonic suites preserved in the eastern Talkeetna Mountains (177.4-168.9 Ma) and the Alaska Peninsula (183.5164.1 Ma). Isotopic data from these four plutonic sections of the Talkeetna arc define a restricted array of initial isotopic ratios that are similar to modern intraoceanic settings. In the western Talkeetna Mountains, inherited Paleozoic zircon and evolved isotopic data are consistent with interaction between the eastern extent of the arc and the Wrangellia terrane. Detrital Archean zircon grains in volcanic rocks and roof pendants on the Alaska Peninsula suggest that this portion of the arc formed in close proximity to older continental crust or terrigenous sediment derived from such crust. However, the isotopic ratios from this area, the absence of inherited zircon in the plutonic samples, and the dearth of preserved prearc crust suggests that there was a limited volume of the older crustal component and that it had little or no impact on the geochemical evolution of most of the arc plutons. The complete data set suggests that the Talkeetna arc formed in a setting similar to the modern western Pacific, with along-strike variations in the tectonic setting that included intraoceanic magmatism in the Chugach Mountains, interaction with the Wrangellia plateau in the western Talkeetna Mountains, and intraoceanic magmatism in the presence of proximal older crust along the Alaska Peninsula.

[24] The large silicic plutonic complexes on the Alaska Peninsula and in the Eastern Talkeetna Mountains, along with the more restricted volumes of evolved plutons in the Chugach Mountains and on the Kodiak archipelago, are chemically similar to the exposed middle crust of the IzuBonin arc in the Tanzawa plutonic complex. Calculated seismic velocities of intermediate to felsic Talkeetna arc plutons range from $\mathrm{V}_{\mathrm{p}}=5.96-6.55 \mathrm{~km} / \mathrm{s}$, suggesting that the Talkeetna plutons represent an analogue for the low-velocity middle crust observed in modern arcs. The continuous temporal record and extensive exposure of intermediate to felsic plutonic rocks throughout the Talkeetna arc suggest that evolved magmas are generated by a steady state or repetitive processes and play a fundamental role in the growth and evolution of intraoceanic arc crust.

[25] Acknowledgments. We thank our collaborators on the Talkeetna arc project: Sue DeBari, Greg Hirth, Jeff Amato, Peter Clift, Jeff Trop, Andrew Greene, Mark Behn, and Amy Draut. We are particularly grateful to Luc Mehl, Terry Pavlis, and Mike Johnsen for help in the field and useful discussions of the data. We thank Katie Kelley, Terry Plank, and Jenn Wade for help with the sample digestions and analyses at Boston University and Sarah Roeske for providing sample 7-20-S12. We thank Cin-Ty Lee, Calvin Miller, and two anonymous reviewers for their useful comments on the manuscript. This research was supported by NSF EAR-9910899. 


\section{References}

Amato, J. M., M. E. Rioux, P. B. Kelemen, G. E. Gehrels, P. D. Clift, T. L. Pavlis, and A. E. Draut (2007), U-Pb geochronology of volcanic rocks from the Jurassic Talkeetna Formation and detrital zircons from prearc and postarc sequences: Implications for the age of magmatism and inheritance in the Talkeetna arc, in Tectonic Growth of a Collisional Continental Margin: Crustal Evolution of Southern Alaska, edited by K. D. Ridgway et al., Spec. Pap. Geol. Soc. Am., 431, 253-271, doi:10.1130/2007.2431(11).

Barker, F., et al. (1994), Some accreted volcanic rocks of Alaska and their elemental abundances, in The Geology of North America, vol. G-1, The Geology of Alaska, edited by G. Plafker and H. C. Berg, pp. 555-587, Geol. Soc. of Am., Boulder, Colo.

Behn, M. D., and P. B. Kelemen (2006), Stability of arc lower crust: Insights from the Talkeetna arc section, south central Alaska, and the seismic structure of modern arcs, J. Geophys. Res., 111, B11207, doi:10.1029/2006JB004327.

Bond, G. C. (1973), A late Paleozoic volcanic arc in the eastern Alaska Range, Alaska, J. Geol., 81, 557-575, doi:10.1086/627907.

Bradley, D. C., T. M. Kusky, P. J. Haeussler, S. M. Kari, and D. T. Donley (1999), Geologic map of the Seldovia quadrangle, south-central Alaska, U.S. Geol. Surv. Open File Rep. OF99-18, 1 sheet.

Calvert, A. J., S. L. Klemperer, N. Takahashi, and B. C. Kerr (2008), Three-dimensional crustal structure of the Mariana island arc from seismic tomography, J. Geophys. Res., 113, B01406, doi:10.1029/ 2007JB004939.

Clift, P. D., A. E. Draut, P. B. Kelemen, J. Blusztajn, and A. Greene (2005a), Stratigraphic and geochemical evolution of an oceanic arc upper crustal section: The Jurassic Talkeetna Volcanic Formation, south-central Alaska, Geol. Soc. Am. Bull., 117, 902-925, doi:10.1130/B25638.1.

Clift, P. D., T. Pavlis, S. M. DeBari, A. E. Draut, M. Rioux, and P. Kelemen (2005b), Subduction erosion of the Jurassic Talkeetna-Bonanza arc and the Mesozoic accretionary tectonics of western North America, Geology, 33, 881-884, doi:10.1130/ G21822.1.

Connelly, W. (1978), Uyak Complex, Kodiak Islands, Alaska: A Cretaceous subduction complex, Geol. Soc. Am. Bull., 89, 755-769, doi:10.1130/00167606(1978)89<755:UCKIAA >2.0.CO;2.

Connelly, W., and J. C. Moore (1979), Geologic map of the northwest side of the Kodiak and adjacent islands, Alaska, U.S. Geol. Surv. Misc. Field Stud. Map, MF-1057, 2 sheets.

Crawford, W. C., J. A. Hildebrand, L. M. Dorman, S. C. Webb, and D. A. Wiens (2003), Tonga Ridge and Lau Basin crustal structure from seismic refraction data, J. Geophys. Res., 108(B4), 2195 , doi:10.1029/2001JB001435.

Csejtey, B., Jr., W. H. Nelson, D. L. Jones, N. J. Silberling, R. M. Dean, M. S. Morris, M. A. Lanphere, J. G. Smith, and M. L. Silberling (1978), Reconnaissance geologic map and geochronology, Talkeetna Mountains quadrangle, northern part of Anchorage quadrangle, and southwest corner of Healy quadrangle, Alaska, U.S. Geol. Surv. Open File Rep., 78-558A.

DeBari, S. M., and R. G. Coleman (1989), Examination of the deep levels of an island arc: Evidence from the Tonsina ultramafic-mafic assemblage, Tonsina, Alaska, J. Geophys. Res., 94, 4373-4391, doi:10.1029/JB094iB04p04373.

DeBari, S. M., R. G. Anderson, and J. K. Mortensen (1999), Correlation among lower to upper crustal components in an island: The Jurassic Bonanza arc, Vancouver Island, Canada, Can. J. Earth Sci., 36, 1371-1413, doi:10.1139/cjes-36-8-1371.

Detterman, R. L., and B. L. Reed (1980), Stratigraphy, structure, and economic geology of the Iliamna quadrangle, Alaska, U.S. Geol. Surv. Bull., 1368-B.
Detterman, R. L., T. Hudson, G. Plafker, R. G. Tysdal, and J. M. Hoare (1976), Reconnaissance geologic map along Bruin Bay and Lake Clark faults in Kenai and Tyonek quadrangles, Alaska, U.S. Geol. Surv. Open File Rep., OF76-477, 1 sheet.

Detterman, R. L., J. E. Case, F. H. Wilson, and M. E. Young (1987), Geologic map of the Ugashik, Bristol Bay, and western part of Karluk Quadrangle, Alaska, U.S. Geol. Surv. Misc. Invest. Ser., Map I-1685.

Detterman, R. L., J. E. Case, J. W. Miller, F. H. Wilson, and M. E. Yount (1996), Stratigraphic framework of the Alaska Peninsula, U.S. Geol. Surv. Bull., 1969-A, $74 \mathrm{pp}$

Ewart, A., and C. J. Hawkesworth (1987), The Pleistocene-recent Tonga-Kermadec arc lavas: Interpretation of new isotopic and rare earth data in terms of a depleted mantle source model, J. Petrol., 28, 495-530

Ewart, A., K. D. Collerson, M. Regelous, J. I. Wendt, and Y. Niu (1998), Geochemical evolution within the Tonga-Kermadec-Lau arc-Back-arc systems: The role of varying mantle wedge composition in space and time, J. Petrol., 39, 331-368, doi:10.1093/ petrology/39.3.331

Farris, D. W. (2009), Construction and evolution of the Kodiak Talkeetna arc crustal section, in Crustal Cross Sections from the Western North American Cordillera and Elsewhere: Implications for Tectonic and Petrologic Processes, edited by R. B. Miller and A. W. Snoke, Spec. Pap. Geol. Soc. Am. 456, 69-96, doi:10.1130/2009.2456(03).

Grantz, A., H. Thomas, T. W. Stern, and N. B. Sheffey (1963), Potassium-argon and lead-alpha ages for stratigraphically bracketed plutonic rocks in the Talkeetna Mountains, Alaska, U.S. Geol. Surv. Prof. Pap., 475-B, B56-B59.

Greene, A. R., S. M. DeBari, P. B. Kelemen, and P. D. Clift (2006), A detailed geochemical study of island arc crust: The Talkeetna arc section, south-central Alaska, J. Petrol., 47(6), 1051-1093, doi:10.1093/ petrology/eg1002.

Hacker, B. R., and G. A. Abers (2004), Subduction factory 3: An Excel worksheet and macro for calculating the densities, seismic wave speeds, and $\mathrm{H}_{2} \mathrm{O}$ contents of minerals and rocks at pressure and temperature, Geochem. Geophys. Geosyst., 5, Q01005, doi:10.1029/2003GC000614

Hacker, B. R., S. R. Wallis, L. Ratschbacher, M. Grove, and G. Gehrels (2006a), High-temperature geochronology constraints on the tectonic history and architecture of the ultrahigh-pressure Dabie Sulu orogen, Tectonics, 25, TC5006, doi:10.1029/ 2005TC001937

Hacker, B. R., L. Mehl, P. B. Kelemen, M. Rioux, and M. D. Behn (2006b), Reconstruction of the Talkeetna intra-oceanic arc of Alaska through thermobarometry, paper presented at Arc Genesis and Crustal Evolution Penrose Conference, Geol. Soc. of Am., Valdez, Alaska.

Hacker, B. R., L. Mehl, P. B. Kelemen, M. Rioux, M. D. Behn, and P. Luffi (2008), Reconstruction of the Talkeetna intraoceanic arc of Alaska through thermobarometry, J. Geophys. Res., 113, B03204, doi:10.1029/2007JB005208.

Hofmann, A. W. (1988), Chemical differentiation of the Earth: The relationship between mantle, continental crust and oceanic crust, Earth Planet. Sci. Lett., 90 297-314, doi:10.1016/0012-821X(88)90132-X

Holbrook, W., D. Lizarralde, S. McGeary, N. Bangs, and J. Diebold (1999), Structure and composition of the Aleutian island arc and implications for continental crustal growth, Geology, 27, 31-34, doi:10.1130/0091-7613(1999)027<0031:SACOTA $>$ 2.3. $\mathrm{CO} ; 2$

Imlay, R. W. (1984), Early and middle Bajocian (Middle Jurassic) ammonites from southern Alaska, U.S. Geol. Surv. Prof. Pap., 1322, 38 pp.

Jaffey, A. H., K. F. Flynn, L. E. Glendenin, W. C. Bentley, and A. M. Essling (1971), Precision mea- surement of half-lives and specific activities of ${ }^{235} \mathrm{U}$ and ${ }^{238} \mathrm{U}$, Phys. Rev. C, 4, 1889-1906, doi:10.1103/PhysRevC.4.1889.

Johnsen, M. (2007), Geochemical composition of the western Talkeetna island arc crustal section, lower Cook Inlet region, Alaska: Implications for crustal growth along continental margins, M.Sc. thesis, 99 pp., West. Wash. Univ., Bellingham.

Johnsen, M., S. DeBari, and M. Rioux (2007), The felsic plutonic core of the western Talkeetna island arc crustal section, Alaska: Its formation and implications for crustal growth along continental margins, paper presented at 103rd Annual Meeting, Cordilleran Sect., Geol. Soc. of Am., West. Wash. Univ., Bellingham.

Jones, D. L., and N. J. Silberling (1979), Mesozoic stratigraphy-The key to tectonic analysis of southern and central Alaska, U.S. Geol. Surv. Open File Rep., 79-1200, 37 pp

Kawate, S., and M. Arima (1998), Petrogenesis of the Tanzawa plutonic complex, central Japan: Exposed felsic middle crust of the Izu-Bonin-Mariana arc, Isl. Arc, 7, 342-358, doi:10.1111/j.1440-1738. 1998.00194.x

Kelemen, P. B., K. Hangøj, and A. R. Greene (2003a), One view of the geochemistry of subduction-related magmatic arcs, with an emphasis on primitive andesite and lower crust, in Treaties on Geochemistry, vol. 3, The Crust, edited by R. Rudnick, pp. 593659, Elsevier, New York

Kelemen, P. B., J. L. Rilling, E. M. Parmentier, L. Mehl, and B. R. Hacker (2003b), Thermal structure due to solid-state flow in the mantle wedge beneath arcs, in Inside the Subduction Factory, Geophys. Monogr. Ser., vol. 138, edited by J. Eiler, pp. 293-311, AGU, Washington, D. C.

Kelemen, P. B., B. R. Hacker, M. Rioux, A. Greene L. Mehl, M. Johnsen, S. DeBari, K. Hanghøj, P. D. Clift, and M. D. Behn (2006), A new mass balance for the Talkeetna arc crustal composition: Comparison with Izu-Bonin and Aleutian arcs, and constraints on crustal genesis, paper presented at Arc Genesis and Crustal Evolution Penrose Conference, Geol. Soc. of Am., Valdez, Alaska.

Kelley, K. A., T. Plank, J. Ludden, and H. Staudigel (2003), Composition of altered oceanic crust at ODP sites 801 and 1149, Geochem. Geophys. Geosyst., 4(6), 8910, doi:10.1029/2002GC000435.

Kodaira, S., T. Sato, N. Takahashi, S. Miura, Y. Tamura, Y. Tatsumi, and Y. Kaneda (2007a), New Seismological constraints on growth of continental crust in the Izu-Bonin intra-oceanic arc, Geology, 35, 1031-1034, doi:10.1130/G23901A.1.

Kodaira, S., T. Sato, N. Takahashi, A. Ito, Y. Tamura, Y. Tatsumi, and Y. Kaneda (2007b), Seismological evidence for variable growth of crust along the Izu intraoceanic arc, J. Geophys. Res., 112, B05104, doi:10.1029/2006JB004593.

Larter, R. D., N. J. Bruguier, and L. E. Vanneste (2001), Structure, composition and evolution of the South Sandwich Islands arc: Implications for rates of arc magmatic growth and subduction erosion, Eos Trans. $A G U, 82(47)$, Fall Meet. Suppl., Abstract T32D-10.

Le Maitre, R. W. (Ed.) (2002), Igneous Rocks: A Classification and Glossary of Terms, 2nd ed., $236 \mathrm{pp}$. Cambridge Univ. Press, Cambridge, U. K

Leat, P. T., J. L. Smellie, I. L. Millar, and R. D. Larter (2003), Magmatism in the south Sandwich arc, in Intra-Oceanic Subduction Systems: Tectonic and Magmatic Processes, edited by L. D. Larter and P. T. Leat, Geol. Soc. Spec. Publ., 219, 285-313, doi:10.1144/GSL.SP.2003.219.01.14.

Lee, J., R. Stern, and S. Bloomer (1995), Forty million years of magmatic evolution in the Mariana arc: The tephra glass record, J. Geophys. Res., 100, 17,671-17,687, doi:10.1029/95JB01685.

Lizarralde, D., W. S. Holbrook, S. McGeary, N. L. Bangs, and J. B. Diebold (2002), Crustal construc- 
tion of a volcanic arc, wide-angle seismic results from the western Alaska Peninsula, J. Geophys. Res., 107(B8), 2164, doi:10.1029/2001JB000230.

Ludwig, K. R. (2003), User's manual for Isoplot 3.00: A geochronological toolkit for Microsoft Excel, Spec. Publ. 4, 70 pp., Berkeley Geochronol. Cent., Berkeley, Calif.

Mattinson, J. M. (2005), Zircon U-Pb chemical abrasion ("CA-TIMS") method: Combined annealing and multi-step partial dissolution analysis for improved precision and accuracy of zircon ages, Chem. Geol., 220, 47-66, doi:10.1016/j.chemgeo. 2005.03.011.

McCulloch, M. T., and M. R. Perfit (1981), ${ }^{143} \mathrm{Nd} /{ }^{144} \mathrm{Nd},{ }^{87} \mathrm{Sr} /{ }^{86} \mathrm{Sr}$ and trace element constraints on the petrogenesis of Aleutian island arc magmas, Earth Planet. Sci. Lett., 56, 167-179, doi:10.1016/ 0012-821X(81)90124-2.

Mehl, L., B. R. Hacker, G. Hirth, and P. B. Kelemen (2003), Arc-parallel flow within the mantle wedge: Evidence from the accreted Talkeetna arc, south central Alaska, J. Geophys. Res., 108(B8), 2375, doi:10.1029/2002JB002233.

Millholland, M. A., C. M. Graubard, J. M. Mattinson, and W. C. McClelland (1987), U-Pb age of zircons from the Talkeetna Formation, Johnson River area, Alaska, Isochron West, 50, 9-11.

Miyashiro, A. (1974), Volcanic rock series in island arcs and active continental margins, Am. J. Sci., $274,321-355$

Nakamura, N. (1974), Determination of REE, Ba, Fe, $\mathrm{Mg}, \mathrm{Na}$ and $\mathrm{K}$ in carbonaceous and ordinary chondrites, Geochim. Cosmochim. Acta, 38, 757-775, doi:10.1016/0016-7037(74)90149-5.

Nelson, W. H., C. Carlson, and J. E. Case (1983), Geologic map of the Lake Clark quadrangle, Alaska, U.S. Geol. Surv. Misc. Field Stud. Map, MF-1114$A, 1$ sheet.

Nokleberg, W. J., D. L. Jones, and N. J. Silberling (1985), Origin and tectonic evolution of the Maclaren and Wrangellia terranes, eastern Alaska Range, Alaska, Geol. Soc. Am. Bull., 96, 12511270, doi:10.1130/0016-7606(1985)96<1251: OATEOT $>2.0 . \mathrm{CO} ; 2$

Nokleberg, W. J., G. Plafker, and F. H. Wilson (1994), Geology of south-central Alaska, in The Geology of North America, vol. G-1, The Geology of Alaska, edited by G. Plafker and H. C. Berg, pp. 311365, Geol. Soc. of Am., Boulder, Colo.

Ogg, J. (2004a), The Jurassic period, in A Geologic Time Scale, edited by F. Gradstein, J. Ogg, and A. Smith, pp. 307-343, Cambridge Univ. Press, Cambridge, U. K.

Ogg, J. (2004b), The Triassic period, in A Geologic Time Scale, edited by F. Gradstein, J. Ogg, and A. Smith, pp. 271-306, Cambridge Univ. Press, Cambridge, U. K.

Ohno, I., K. Harada, and C. Yoshitomi (2006), Temperature variation of elastic constants of quartz across the $\alpha-\beta$ transition, Phys. Chem. Miner., 33, doi:10.1007/s00269-005-0008-3.

Pálfy, J., P. L. Smith, J. K. Mortensen, and R. M. Friedman (1999), Integrated ammonite biochronology and $\mathrm{U}-\mathrm{Pb}$ geochronometry from a basal Jurassic section in Alaska, Geol. Soc. Am. Bull., 111, 1537 1549, doi:10.1130/0016-7606(1999)111<1537: IABAUP $>2.3 . \mathrm{CO} ; 2$.

Pavlis, T. L., D. H. Monteverde, J. R. Bowman, J. L. Rubenstone, and M. D. Reason (1988), Early Cretaceous near-trench plutonism in southern Alaska: A tonalite-trondhjemite intrusive complex injected during ductile thrusting along the Border Ranges
Fault system, Tectonics, 7, 1179-1199, doi:10.1029/ TC007i006p01179.

Pearce, J. A., P. E. Baker, P. K. Harvey, and I. W. Luff (1995), Geochemical evidence for subduction fluxes, mantle melting and fractional crystallization beneath the south Sandwich Island arc, J. Petrol., $36,1073-1109$.

Plafker, G., W. J. Nokleberg, and J. S. Lull (1989), Bedrock geology and tectonic evolution of the Wrangellia, Peninsular, and Chugach terranes along the trans-Alaska crustal transect in the Chugach Mountains and southern Copper River Basin, Alaska, J. Geophys. Res., 94, 4255-4295, doi:10.1029/ JB094iB04p04255.

Richter, D. H., and D. L. Jones (1973), Structure and stratigraphy of the eastern Alaska Range, Alaska, in Arctic Geology, AAPG Mem., 19, 408-420.

Ridgway, K. D., J. M. Trop, W. J. Nokleberg, C. M. Davidson, and K. R. Eastham (2002), Mesozoic and Cenozoic tectonics of the eastern and central Alaska Range: Progressive basin development and deformation in a suture zone, Geol. Soc. Am. Bull., 114, 1480-1504, doi:10.1130/0016-7606(2002) $114<1480$ :MACTOT $>2.0$. CO;2

Riehle, J. R., R. L. Detterman, M. E. Yount, and J. W. Miller (1993), Geologic map of the Mount Katmai quadrangle and adjacent parts of the Naknek and Afognak quadrangle, Alaska, U.S. Geol. Surv. Misc. Invest. Ser. Map I-2204, 1 sheet.

Rioux, M. (2006), The growth and differentiation of arc crust: Temporal and geochemical evolution of the accreted Talkeetna arc, south-central Alaska, $\mathrm{Ph}$. D. thesis, Univ. of Calif., Santa Barbara.

Rioux, M., B. Hacker, J. Mattinson, P. Kelemen, J. Blusztajn, and G. Gehrels (2007), Magmatic development of an intra-oceanic arc: High precision $\mathrm{U}-\mathrm{Pb}$ zircon and whole rock isotopic analyses from the accreted Talkeetna arc, south-central Alaska, Geol. Soc. Am. Bull., 119, 1168-1184, doi:10.1130/ B25964.1.

Roeske, S., J. Mattinson, and R. Armstrong (1989), Isotopic ages of glaucophane schists on the Kodiak Islands, southern Alaska, and their implications for the Mesozoic tectonic history of the Birder Ranges fault system, Geol. Soc. Am. Bull., 101, 10211037, doi:10.1130/0016-7606(1989)101<1021: IAOGSO $>2.3 . \mathrm{CO} ; 2$

Shillington, D. J., H. J. A. Van Avendonk, W. S. Holbrook, P. B. Kelemen, and M. J. Hornbach (2004), Composition and structure of the central Aleutian island arc from arc-parallel wide-angle seismic data, Geochem. Geophys. Geosyst., 5, Q10006, doi:10.1029/2004GC000715.

Silberling, N. J., D. L. Jones, J. W. H. Monger, P. J. Coney, H. C. Berg, and G. Plafker (1994), Lithotectonic terrane map of Alaska and adjacent parts of Canada, in The Geology of North America, vol. G-1, The Geology of Alaska, edited by G. Plafker and H. C. Berg, Plate 3, Geol. Soc. of Am., Boulder, Colo.

Sisson, V. B., and T. C. Onstott (1986), Dating blueschist metamorphism: A combined ${ }^{40} \mathrm{Ar} /{ }^{39} \mathrm{Ar}$ and electron microprobe approach, Geochim. Cosmochim. Acta, 50, 2111-2117, doi:10.1016/00167037(86)90264-4.

Streckeisen, A. (1973), Plutonic rocks: Classification and nomenclature recommended by the IUGS Subcommision on the Systematics of Igneous Rocks, Geotimes, 18(10), 26-30.

Streckeisen, A. (1976), To each plutonic rock its proper name, Earth Sci. Rev., 12, 1-33, doi:10.1016/00128252(76)90052-0.
Suyehiro, K., N. Takahashi, Y. Ariie, Y. Yokoi, R. Hino, M. Shinohara, T. Kanazawa, N. Hirata H. Tokuyama, and A. Taira (1996), Continenta crust, crustal underplating, and low-Q upper mantle beneath an oceanic island arc, Science, 272, 390 392, doi:10.1126/science. 272.5260 .390

Takahashi, N., K. Suyehiro, and M. Shinohara (1998), Implications from the seismic crustal structure of the northern Izu-Bonin arc, Isl. Arc, 7, 383-394, doi:10.1111/j.1440-1738.1998.00197.x.

Takahashi, N., S. Kodaira, S. Klemperer, Y. Tatsumi, Y. Kaneda, and K. Suyehiro (2007), Crustal struc ture and evolution of the Mariana intra-oceanic island arc, Geology, 35, 203-206, doi:10.1130/ G23212A.1.

Taylor, R. N., and R. W. Nesbitt (1998), Isotopic characteristics of subduction fluids in an intra-oceanic setting, Izu-Bonin arc, Japan, Earth Planet. Sci. Lett., 164, 79-98, doi:10.1016/S0012-821X(98) 00182-4.

Trop, J. M., D. A. Szuch, M. Rioux, and R. B. Blodgett (2005), Sedimentology and provenance of the Upper Jurassic Naknek Formation, Talkeetna Mountains, Alaska: Bearings on the accretionary tectonic history of the Wrangellia composite terrane, Geol. Soc. Am. Bull., 117, 570-588, doi:10.1130/ B25575.1.

Van Avendonk, H. J. A., D. J. Shillington, W. S. Holbrook, and M. J. Hornbach (2004), Inferring crustal structure in the Aleutian island arc from a sparse wide-angle seismic data set, Geochem. Geophys. Geosyst., 5, Q08008, doi:10.1029/2003GC000664.

Wallace, W. K., C. L. Hanks, and J. F. Rogers (1989), The southern Kahiltna terrane: Implications for the tectonic evolution of southwestern Alaska, Geol. Soc. Am. Bull, 101, 1389-1407, doi:10.1130/ 0016-7606(1989)101<1389:TSKTIF>2.3.CO;2.

Wilson, F. H., J. H. Dover, D. C. Bradley, F. R. Weber, T. K. Bundtzen, and P. J. Haeussler (1998), Geolog ic map of central (interior) Alaska, U.S. Geol. Surv. Open File Rep., 98-133.

Winkler, G. R. (1992), Geologic map and summary geochronology of the Anchorage $1^{\circ} \times 3^{\circ}$ quadrangle, southern Alaska, U.S. Geol. Surv. Misc. Invest. Ser., Map I-2283.

Winkler, G. R., M. L. Silberman, A. Grantz, R. J. Miller, and E. M. MacKevett Jr. (1981), Geologic map and summary geochronology of the Valdez quadrangle, southern Alaska, U.S. Geol. Surv. Open File Rep. $80-892-A$.

Woodhead, J. D. (1989), Geochemistry of the Mariana arc (western Pacific): Source composition and processes, Chem. Geol., 76, 1-24, doi:10.1016/00092541(89)90124-1.

J. Blusztajn and K. Hanghøj, Department of Geology and Geophysics, Woods Hole Oceanographic Institute, Woods Hole, MA 02543, USA.

G. Gehrels, Department of Geosciences, University of Arizona, Tucson, AZ 85721, USA.

B. Hacker and J. Mattinson, Department of Earth Science, University of California, Santa Barbara, CA 93106, USA.

P. Kelemen, Lamont-Doherty Earth Observatory, Earth Institute at Columbia University, 58 Geochemistry Building, Palisades, NY 10964, USA

M. Rioux, Department of Earth, Atmospheric and Planetary Sciences, Massachusetts Institute of Technology, Cambridge, MA 02139, USA. (riouxm@ mit.edu) 